IJ§ER

ISSN: 2149-5939
International Journal of Social Sciences and Education Research

Online, https://dergipark.org.tr/tr/pub/ijsser

Volume: 8(1), 2022

\title{
Ortaokul Türkçe derslerinde dinleme sürecine yönelik uygulamalar üzerine bir araştırma
}

\section{A Research on practices for listening process in secondary school Turkish lessons}

\author{
Ceyda Çaylı ${ }^{1}$ ve Ali Göçer ${ }^{2}$ \\ ${ }^{1}$ Türkçe Öğretmeni, Milli Ĕ̆itim Bakanll̆ğ, e-mail: cydcayli@gmail.com, ORCID: https://orcid.org/0000-0002-6091-4811 \\ 2 Prof. Dr., Erciyes Üniversitesi, Eğitim Fakültesi, Türkçe ve Sosyal Bilimler Eğitimi Bölümü, e-mail: gocer@erciyes.edu.tr, ORCID: \\ https://orcid.org/0000-0002-6880-2611
}

\begin{tabular}{|c|c|}
\hline Makale Bilgisi & $\ddot{O} z$ \\
\hline Araştırma Makalesi & Araştırmanın amacl; dinleme becerisinin gelişimini desteklemek ve gelişim durumunu belir- \\
\hline Gönderilme.28 Ă̆ ustos 2021 & lemeye çalışmaktır. Araştırma nitel araştırma yaklaşımı çerçevesinde eylem araştırması de- \\
\hline $\begin{array}{l}\text { Gonderilme:28 Agustos } 2021 \\
\text { Düzeltme: } 26 \text { Kasim } 2021\end{array}$ & $\begin{array}{l}\text { seniyle yürutulmüşür. Araştırmanın çalışma grubunu, Kayseri merkezde yer alan bir orta- } \\
\text { okulun 6. sınıfinda eğitim gören } 23 \text { öğrenci oluşturmaktadır. Araştırmadaki veriler; öğrenci }\end{array}$ \\
\hline Kabul: 28 Kasim 2021 & $\begin{array}{l}\text { dokümanları, gözlem formları, yarı yapılandırılmış görüşme formları, araștırmacı günlüğü } \\
\text { ve öğrenci günlüklerinden elde edilmiştir. Elde edilen veriler içerik analizi ve betimsel ana- }\end{array}$ \\
\hline Anahtar kelimeler: & liz yapılarak yorumlanmıștır. Araștırma sonunda; dinleme öncesine yönelik kazanımlardaki \\
\hline Dinleme becerisi, & eksikliklerin giderilmesinin, metne hazırlık uygulamalarının ayrıntılı olarak yapılmasının, \\
\hline Dinleme uygulamalarl, & geleneksel ve tamamlayıcı ölçme değerlendirme uygulamalarının etkili şekilde kullanımının \\
\hline Eylem araştırması & $\begin{array}{l}\text { önemi fark edilmiştir. Ayrıca dinleme metninin niteliğine göre dinleme sayısı, dinleme stili } \\
\text { ve dinleme metninin sunuluş şeklinin belirlenmesinin; dinleme metni ve konusunun orijinal } \\
\text { olmasının, dinleme metinlerinin, ses dosyalarının ve görsel destekli materyallerin nitelikli } \\
\text { olmasının sürece etki ettiği ortaya çımıştır. }\end{array}$ \\
\hline
\end{tabular}

\begin{tabular}{|c|c|}
\hline Article Info & Abstract \\
\hline $\begin{array}{l}\text { Research Article } \\
\text { Received: } 28 \text { August } 2021 \\
\text { Revised: } 26 \text { November } 2021 \\
\text { Accepted: } 28 \text { November } 2021 \\
\text { Keywords: } \\
\text { Listening skill, } \\
\text { Listening practices, } \\
\text { Action research }\end{array}$ & $\begin{array}{l}\text { The purpose of the research is to promote the progress and to try to determine the develop- } \\
\text { ment. In the research it's adopted the action research approach which is thought as appro- } \\
\text { priate for solution of the problem. The working group of the research is formed of the } 23 \\
\text { students in } 6^{\text {th }} \text { grade in a secondary school in the center of Kayseri. Data in the survey; } \\
\text { documents of students, observation forms, semi structural interview forms, researcher's di- } \\
\text { ary and the student's diary. The obtained data is interpreted through making content anal- } \\
\text { ysis and descriptive analysis. In the end of the research, the importance of resolving the } \\
\text { lacking parts in learning outcome before listening, being done the preparative implementa- } \\
\text { tions in detail, the use of traditional and supplementary assessment and evaluation effi- } \\
\text { ciently have been noticed. Besides it is understood that according to the quality of the lis- } \\
\text { tening text, the number of listening, the style of listening and the style of the presentation of } \\
\text { listening texts, the originality of listening text and theme being in a good condition, listening } \\
\text { text, voice files and, visual materials being qualified effect the process. }\end{array}$ \\
\hline
\end{tabular}

\section{Giriş}

Ana dili öğretimiyle bireylerin temel dil becerilerini kazanması ve bunu sosyal hayatlarında etkili bir şekilde kullanması amaçlanmaktadır. Günlük hayatımızda, okullarda öğrenilen/öğretilen her şeyden daha çok "dil becerileri” kullanılmaktadır. Bu dil becerilerinden bir olan dinleme becerisi insanlar için en temel olanı ve insanın

\footnotetext{
* Bu araştırma "Ortaokul Türkçe derslerinde öğrencilerin dinleme becerisinin geliştirilmesi ve gelişim durumlarının belirlenmesine yönelik bir eylem araştırması" adlı doktora tezinden üretilmiştir.

Bu araştırma Kayseri Valiliği, İl Millî Eğitim Müdürlüğü tarafindan 11.01.2018 tarihinde, 94025929-609,02-E.852280 sayıll izin belgesi alınarak yürütülmüşü̈r. Tüm sorumluluk yazara aittir.

Kaynak göster: Çaylı, C. \& Göçer, A. (2022). Ortaokul Türkçe derslerinde dinleme sürecine yönelik uygulamalar üzerine bir araştırma. International Journal of Social Sciences and Education Research, 8 (1), 21-43. DOI: https://doi.org/10.24289/ijs$\underline{\text { ser. } 988108}$
} 
edindiği ilk dil becerisidir (Doğan, 2008: 269; İșeri ve Y1lmaz, 2008: 12; Yıldız, 2015: 20) "Dinleme insanların yaşamında önemli bir rol oynar. İletişim becerilerinin ve dilin dört ana alanından (dinleme, konuşma, okuma ve yazma) biri olan dinleme en temel olanıdır" (Gilakjani ve Ahmadi, 2011: 783). Dil becerileri içerisinde, insanın doğuştan elde ettiği bir beceri olan "dinleme becerisi” (Emiroğlu ve Pınar, 2013:769; Melanlığlu, 2012a:1584; Melanlıŏlu, 2012b:65; Özbay, 2006:43; Yıldız, 2015:20) diğer becerilerden daha fazla hayatımızda yer almaktadır. İnsan iletişimde olduğu zamanın yaklaşık olarak \%40-50'sini dinleme ile geçirmektedir (Rivers; akt. Gilman ve Moody, 1984:331; Burely ve Alan, 1995; akt. Miller, 2003). Bu oranın ilköğretim öğrencilerinin okul zamanlarında \%50 (İnan, 1998; akt. Çif̧̧i, 2001:169) ve hatta \%83 (Çifçi, 2001:169) olduğu ifade edilmektedir. Ayrıca üniversite düzeyinde dinlemenin \%90'lara ulaştı̆̆ (İnan, 1998; akt. Çifçi, 2001:169) ve insanların bildiklerinin \%80'ini dinlediklerinden öğrendikleri de ifade edilmektedir (Hunsaker 1990; akt. Akyol, 2010:1). Literatürde yer verilen bu oranlar, dinleme becerisinin insan hayatındaki önemini göstermektedir.

Günlük hayatımızda önemli bir yeri olan dinleme becerisinin eğitim ortamlarına etkisi büyüktür. Sosyal ilişkilerimizde etkin rol oynayan dinleme becerisinin gelişiminin desteklenmesi öğrencinin öğrenme başarısına etki etmektedir. "Öğrenme çoğu zaman dinleme yoluyla gerçekleşmektedir" Göçer (2007: 19). Hayatın her alanına etkileri olan dinleme becerisi, diğer dil becerileri kadar okullarda geliştirilememektedir. "Diğer üç dil becerisi (okuma, yazma ve konuşma) doğrudan dikkat çekerken, öğretmenler, öğrencilerin dinleme becerilerini yardım almaksızın kendilerinin geliştirmesini beklemektedirler" (Mendelsohn,1984; Oxford, 1993; akt. Osada, 2004: 54). $\mathrm{Bu}$ duruma; dinleme becerisinin doğuştan elde edilen bir beceri (Yıldız, Okur, Arı ve Yılmaz, 2010: 179; Özbay, 2006: 43; Melanlığlu, 2012a: 1584) ve okula gelen öğrencilerin konuşma ve dinlemeyi okula gelmeden önce biliyor olması (Doğan, 2013: 154) sebep olarak görülmektedir. Dinleme becerisi üzerine yapılan çalışmaların yetersiz olduğu düşünülse de (Akyol, 2010: 1; Buley-Allen, 1995; akt. Doğan, 2013: 154; Çif̧çi, 2001: 166; Doğan, 2013: 154; Yıldız vd. 2010: 186), bu alandaki araştırmaların artış gösterdiği ifade edilmektedir (Kardaş, Çetinkaya ve Kaya, 2018: 21; Kemiksiz, 2017: 511; Miller, 2003).

Yapılan ve yürütülen araştırmalarla, geliştirilebilir bir beceri olduğu kabul edilen dinleme becerisi (Cihangir Çankaya, 2015; Çaylı, 2012; Doğan, 2008; Epçaçan, 2013; Melanlığlu, 2012a) üzerine literatürde farklı tanımlarla karşılaşılmaktadır. Dinleme "Dinleyicilerin yeni bilgi elde etmek için, bildiklerini kullanması ve daha sonra yaratıcı zihinsel etkinlik içerisinde söylenilenin anlam ifade etmesi için konuşulan metni anlamasını içeren karmaşık ve etkileşimli bir süreçtir" (Xiao-yun ve Gui-rong, 2011:316). "Dinleme; dil sesini ve görsel açıdan dinleme aktivesini içeren, tanımlanma, yorumlanma, değer verme ve anlamın içeriğine tepki verme sürecidir" (Bello, 2018: 64). Ayrıca dinleme ile işitme arasında fark bulunmaktadır.

"İşitme fiziksel bir dururumken, dinleme, içine işitmeyi de alan aktif bir zihinsel süreçtir” (Doğan, 2013: 153). Dinleme sürecinde "İyi bir dinleyici, bir mesaja odaklanmak için duyduklarının çoğunu süzdüğü için dinlemek işitmekten daha fazlasıdır" (Jalongo, 1995: 13). Özetle dinleme "Kişiler arasında iletişimin vazgeçilmez bir unsuru, anlatıcıdan gelen mesajları anlama ve yorumlama çabası; işitmeyi de içine alan kapsamlı, karmaşık, aktif bir süreç; çok boyutlu bir olgu; amaçlı bir davranış ve insanın seçme özgürlüğünün de bir yansıması olarak insan beyninin bilişsel süreçlerini gerektiren zihinsel bir etkinliktir" (Epçaçan, 2013: 335). Dinleme üzerine yapılan tanımlardan hareketle; "Dinleme; işitmenin ötesinde, dinleyicinin uyarana karşı dikkat kesilerek, önceki bilgileriyle yeni öğrenmelerini ilerlettiği zihinsel bir süreçtir" şeklinde de tanımlanabilir.

Yapılan bu araştırma ile öğrencilerin dinleme becerisinin geliştirilmesi, dinleme sürecine etki eden unsurlara ve dinleme metinlerinin taşıması gereken niteliklerine dikkat çekilmesi, dinleme becerisinin gelişim durumunun belirlenmesi, Türkçe Öğretim Programında görülen eksiklerin fark edilmesi ve ilgili literatüre katkı sağlanması amaçlanmaktadır. Yürütülen araştırmanın; dinleme becerisinin gelişimine ve gelişim durumuna yönelik uygulamalara yer vermesi, öğrencilerin dinleme metinlerine yönelik algılarını değiştirmesi, dinleme becerisinin gelişimi ve gelişim durumunun belirlenmesine yönelik yürütülen uygulamalarla öğrencilerin gelişimine katkı sağlaması, uygulamalardaki eksik ve yanlışlıkların fark edilerek sonraki araştırmalara ışık tutması bakımından önemli olduğu düşünülmektedir. Araştırmanın nitel araştırma yaklaşımı çerçevesinde eylem araştırması deseniyle yürütülmüş olması dersin dinamik sürecinin farklı açılardan yansıtılmasına olanak sağlamıştır. Alanda yapılan uygulamalar ve araştırmalar dinleme becerisinin gelişimine etki etmektedir. Bu sebeple dinleme becerisinin gelişimine ve gelişim durumuna yönelik yürütülen uygulamaları temel alan araştırmaların dinleme becerisine katkı sağlayacağı düşünülmektedir.

\section{Yöntem}

Araştırma nitel araşıırma yaklaşımı çerçevesinde eylem araştırması deseniyle yürütülmüştür. Araştırmanın çalışma grubunu, Kayseri merkezde yer alan bir ortaokulun 6. sınıfinda eğitim gören 23 öğrenci oluşturmaktadır. Copyright $(\mathcal{O} 2022$ by IJSSER 
Araştırma Kayseri Valiliği, İl Millî Eğitim Müdürlüğü tarafindan 11.01.2018 tarihinde, 94025929-609,02E.852280 sayılı izin belgesi alınarak yürütülmüştür. Araştırmada yer alan örneklem amaçlı olarak seçilmiştir. "Amaçlı örnekleme zengin bilgiye sahip olduğu düşünülen durumların derinlemesine çalışılmasına olanak vermektedir. Bu anlamda amaçlı örnekleme yöntemleri pek çok durumda, olgu ve olayların keşfedilmesinde ve açıklanmasında yararlı olur" (Patton, 1987; akt. Yıldırım ve Şimşek, 2008: 107). Araştırmadaki katılımcılara yönelik herhangi özel bir bilgi araştırmada verilmemiştir. "Katılımcılar kimliklerinin belirtilmesini istemez ise, katılımc1ların kimlik veya başka herhangi bir kişilik bilgisi verilmemelidir." (McNiff ve Whitehead, 2011: 96.) Bu etik anlayış dikkate alınarak öğrenciler Ö1, Ö2, Ö3... şeklinde ifade edilmiştir.

Araştırmadaki veriler; öğrenci dokümanları, gözlem formları, yarı yapılandırılmış görüşme formları, araştırmacı günlüğü ve öğrenci günlüklerinden elde edilmiştir. Öğrencilerden elde edilen veriler eylem planının bir parçası olarak ders esnasında gönüllülük esasına göre alınmıştır. Elde edilen veriler içerik analizi ve betimsel analiz yapılarak yorumlanmışıtır. Ortaya çıkan temaların belirlenmesinde öncelikle tümevarımsal bir bakış açısıyla hareket edilmiştir, ardından araştırmada belli bir aşamaya ulaşınca hem tümevarımsal hem tümdengelimsel bir anlayış benimsenmiştir. Elde edilen veriler içerik analizi yapılırken tümevarımsal anlayış ön planda olmuştur.

Eylem araştırması "eğitimin uygulayıcıları olan öğretmen, yönetici ve diğer okul çalışanlarının yaptıkları işi daha iyi anlamalarına, eğitim ve öğretimde arzu edilen iyileşme ve değişmeyi gerçekleştirmeye etki etmelerine, uygulamada karşılaştıkları sorunları sistemli yollar kullanarak çözümlemelerine yardımcı olabilecek bir yöntem" (Aksoy, 2003: 474) olarak ifade edilmektedir. Bu sebeple araştırmamızda ele alınan problemin ruhuna uygun olduğu düşünülen eylem araştırması yaklaşımı benimsenmiştir. Ayrıca; araştırmacının öğretmen olarak çalışması ve eylem araştırmasının araştırmacının sürece aktif katılımına imkân tanıması yöntem seçiminde etkili olmuştur.

"Eylem araştırması terimi ilk olarak Kurt Lewin tarafindan kullanılmıştır” (Baumfield, Hall ve Wall, 2013: 3). "Lewin'in çalışmaları bugün Eylem Araştırması (AR) olarak adlandırılan şeyin temel yapı taşıdır" (Greenwood ve Levin, 2007: 18). Ancak günümüz eylem araştırmasının temeli Stenhouse ile atılmıştır. “1940'lardaki Lewin'in çalışmalarında eylem araştırmasının Corey (1953) tarafindan eğitimi ilerletmek amacıyla geliş̧tirildiği düşünülüyordu. Fakat eylem araştırması modern kullanımını, öğretmen uygulamalarının araştırılmasını ve bu araştırmaların öğretmenlerin kendileri tarafından yapılmasını öneren Stenhouse'un 1970'lerdeki çalışmalarına borçludur"' (Stenhouse, 1975; akt. McAteer, 2013: 14-15). Zeichner (2001) araştırmasında eğitimde eylem araştırmasının gelişimini açıklar; Kurt Lewin, Stephen Corey, Lawrence Stenhouse, John Elliot, Stephen Kemmis, Robin McTaggert gibi bazı akademisyenlerin bu gelişimdeki katkısından ve eylem araştırmasının dünyadaki yayılma sürecinden bahseder (bk. Schmuck, 2009: 25-26).

Eylem araştırması sürecine yönelik literatür incelendiğinde, farklı adımlar ile karşılaşılmaktadır. Ancak bu adımlardaki farklılığa rağmen ortak olan eylem araştırmasındaki döngüsel anlayış̧ır. Araştırmacılar eylem araştırmasının döngüsel sürecini kabul etmektedir (Berg ve Lune, 2015; McNiff ve Whitehead 2011; McAteer, 2013; O'Brien, 2001; Stringer, 2014; Tüzel, 2012; Townsend, 2013; Johnson, 2015; Baumfield vd, 2013). Araştırmacılar tarafından ifade edilen eylem araştırması süreçleri şu şekildedir: "Planla, uygula, değerlendir (her adım kendi içinde; bak, düşün, eyleme geç şeklindedir)" (Stringer, 2014: 9). Johnson (2015) eylem araştırması süreci beş temel adım ve bölüm içerdiğini ifade ederek bölümleri şu şekilde açıklar: "ilki, soru sormak, bir problem durumu belirlemek veya inceleme alanı tanımlamaktır. İkincisi, hangi verileri toplamak zorunda olduğunuza, bu verilerin nasıl ve hangi sıklıkla toplanması gerektiğine karar verin. Üçüncüsü, verileri toplayın ve analiz edin. Dördüncüsü, bulgularınızın nasıl kullanılabileceği ve uygulanabileceğini betimleyin. Bulgularınızı betimleyerek eylem için plan yapın. Ve son olarak bulgularınızı paylaşın veya rapor edin ve diğerleriyle eylem için planlayın" (s. 19). McAteer (2013) eylem araştırması döngüsünü şu şekilde sıralamıştır: "1. Başla, bir araştırma sorusu netleştir. 2. Mevcut durum nedir ve nasıl bulacağım? 3. Ne değişiklik yapabilirim? Eylem adımları. 4. Değişikliklerin etkilerini değerlendir. 5. Bulguların 1şı̆̆ında asıl araştırma soruna başvur" (s. 32-33). "Eylem araştırması disiplinli, sistemli bir süreç olmayı hedefler. Kavramsal olarak eylem araştırması planı: durumu fark et, sorunu tanımla, çözüm yolu düşün, dene, ne olduğunu göstermek için veri toplayarak eylemi izle, ne olduğuyla ilgili karar vermek için izlek (prosedür) kurarak ilerlemeyi değerlendir, bilginin geçerliliğini test et, değerlendirmeler ışığında uygulamayı değiştir" (McNiff ve Whitehead, 2011:8). Araştırmada yukarıda ifade edilen Johnson (2015), McAteer (2013), McNiff ve Whitehead (2011)'in eylem araştırması süreçleri temel alınmıştır. Aşağıdaki şekilde araştırma süresince takip edilen eylem adımları verilmektedir. Oluşturulan eylem adımları, yürütülecek eylem araştırmasının sürecine uygun olarak geliştirilmiştir. 
Şekil 1. Eylem adımları

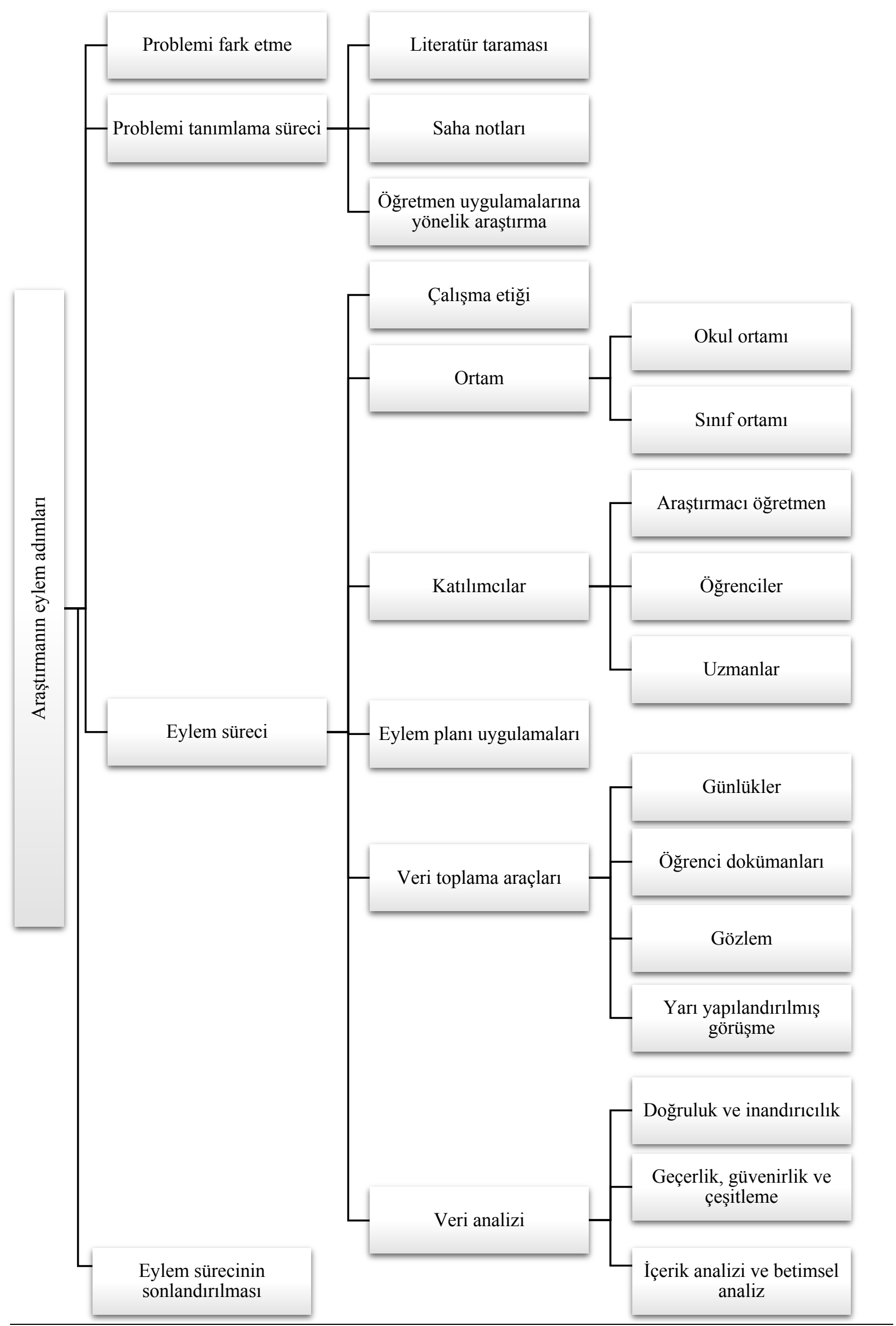




\section{Bulgular}

Araştırmada dinleme sürecine yönelik uygulamalar planlanırken 2018 Türkçe Dersi Öğretim Programında yer alan 6. sınıf kazanımları dikkate alınmıştır. Ancak dinleme öncesine yönelik bu sınıf düzeyinde herhangi bir kazanım olmadığı ilk eylem planında görülmüştür. Bu durum neticesinde derse hazırlık uygulamalarının gerekli olduğu düşünülmüş ve genel ders işleyiş anlayışına uygun olarak, hazırlanacak bütün eylem planlarında dinleme öncesine yönelik uygulamalara yer verilmiştir. Yürütülen uygulamalar sonrasında dinleme öncesi yeterli hazırlık yapılmasının dinlediğini anlama başarısına etki ettiği görülmüştür. Dinleme öncesine yönelik uygulamalarda çalışma yapraklarına yer verilmiştir. Çalışma yaprakları sadece dinleme öncesinde değil dinleme sürecinin bütün aşamalarında uygulamalara dâhil edilmiştir. Araştırmacı öğretmen tarafından hazırlanan çalışma yaprakları öğrencilerin ilgisini çekmiştir.

Tablo 1. EP1'de materyal kullanımına yönelik AG'den elde edilen veriler

\begin{tabular}{lcc}
\hline Araştırmacı günlüğünden cümleler & Kod & Tema \\
\hline $\begin{array}{l}\text { Öğrenciler öğretmen tarafından hazırlanan bir materyali aldığı için mutlu görünüyordu. } \\
\text { Ellerinde bulunan çalışma kitaplarıyla ders işlemeye alışkın olan ögrencilerin gülümse- } \\
\text { meleri ve fisıldaşmaları dikkat çekiciydi. } 12.02 .2018 \text { - s. } 1 .\end{array}$ & $\begin{array}{c}\text { Öğrenciye etki } \\
\text { etme }\end{array}$ & $\begin{array}{c}\text { Materyal } \\
\text { kullanımı }\end{array}$ \\
\hline $\begin{array}{l}\text { (*E=Eylem Planı. Eylem planı araştırma boyunca tablolarda “EP” olarak gösterilmiştir. Araştırma süresince kullanılan eylem } \\
\text { planlarının uygulanma sırası ise tablolarda "EP1, EP2, ..." şeklinde verilmiştir.) } \\
\text { (**AG=Araştırmacı Günlüğü. Araştırmacı günlüğü araştırma boyunca tablolarda “AG” olarak ifade edilmiştir.) }\end{array}$
\end{tabular}

Öğrencilerin süreçte alışkın olmadıkları bir materyalle karşılaşması derse olan ilgiyi artırmıştır. Öğrencilerin farklı bir materyale yönelik tutumları yukarıdaki verilerden anlaşılmıştı. Ayrıca incelenen öğrenci günlüklerindeki ifadeler de bu durumu desteklemektedir.

Tablo 2. EP1'de materyal kullanımına yönelik ÖG'den elde edilen veriler

\begin{tabular}{lcc}
\hline Öğrenci günlüğünden cümleler & Kod & Tema \\
\hline $\begin{array}{l}\text { Ö7: Öğretmenimizin bize etkinlikler vermesi çok güzeldi. Konunun daha güzel } \\
\text { ve akılda kalıcı olmasını sağladı. Ö10: Hocamızın verdiği fotokopiler iyiydi. Her } \\
\text { metinde böyle yapsak güzel olur. Ö11: Bence bu metin ve etkinlikler diğer me- } \\
\text { tinlerden çok daha iyiydi. }\end{array}$ & Çalışma yaprakları & Materyal \\
kullanımı
\end{tabular}

(*ÖG=Öğrenci Günlüğü. Öğrenci günlüğü araştırma boyunca tablolarda “ÖG” olarak ifade edilmiştir.)

Dinleme öncesine yönelik hazırlanan çalışma yapraklarında; metnin içeriğine, metnin türüne, metinde geçecek olan sözcüklere, ön bilgilerin kontrolüne yönelik sorulara ve metne karşı istekliliği artıracak çalışmalara yer verilmiştir. Dinleme öncesi süreçte çalışma yapraklarının yanı sıra öğrencileri derse hazırlamak için eylem araştırması süresince piyes, oyun vb. uygulamalarda bulunulmuş, ayrıca görsel içerikli materyaller kullanılmıştır. Araştırmacı öğretmen tarafından hazırlanan bilgisayar sunuları, perde gösterileri, video vb. uygulamalar öğrencilerin dinleme metnine hazırlanmasında etkili olmuştur.

Dinleme öncesi derse hazırlık çalışmaları her eylem planında bir ders saati olacak şekilde düzenlenmiştir. Eylem planlarında yer alan derse hazırlık uygulamaları dinleme metninin içerik, tür, uzunluk vb. unsurları dikkate alınarak seçilmiş, uygulama öncesi ve sonrasında alan uzmanı ile görüşmeler yapılarak tasarlanan eylem planı ve kullanılacak veri toplama araçları değerlendirilmiştir. Öğrencilerin hazırbulunuşluk düzeylerini artırmayı amaçlayan uygulamaların etkisi çalışma yaprakları, öğrenci günlükleri, araştırmacı günlüğü ve gözlem formlarındaki verilerden elde edilmiştir. Eylem araştırması sonunda uygulanan yarı yapılandırılmış görüşme formları da öğrencilerin yapılan hazırlık çalışmalarının dinleme metinlerini daha iyi anlamalarına katkı sağladığını ortaya koymuştur.

Tablo 3. EP4'te metne görsel hazırlığa yönelik AG'den elde edilen veriler

\begin{tabular}{lcc}
\hline Araştırmacı günlüğünden cümleler & Kod & Tema \\
\hline $\begin{array}{l}\text { Öğrencilerin videoyu izlerken gülümsedikleri, izlediklerinden hareketle tahminde } \\
\text { bulunmaya çok istekli oldukları görüldü. Ayrıca hazırlanan görsel destekli bu mater- } \\
\text { yallerin öğrencilerin dikkatini çektiği fark edildi. Öğrencilerin dinleme öncesi vide- } \\
\text { olar izlenirken hazırlanan materyalde neler olduğuna yönelik sorular sorduğu, izle- } \\
\text { yecekleri hakkında merak duydukları anlaşıldı. 22.03.2018- s. 7. }\end{array}$ & Video kullanma & Merak etme \\
\hline
\end{tabular}


Tablo 4. EP7'de metne görsel hazırlığa yönelik GN'den elde edilen veriler

\begin{tabular}{|c|c|c|}
\hline Gözlem notları & Kod & Tema \\
\hline Tarih: 30.04.2018 - Saat: 07.40- 07.45 & & \\
\hline $\begin{array}{l}\text { Öğrenciler dinleme öncesinde, hazırlanan video izletildi. Video perde gösterisi olarak } \\
\text { hazırlanmıştı. Öğrenciler gösteriyi izlerken çok eğleniyor gibi görünüyordu. Sesli gü- } \\
\text { lüşmeler olduğu görüldü, sinıfın tümü gözünü akıllı tahtadan ayırmıyordu. Hazırlanan } \\
\text { perde gösterisi öğrencilerin ilgisini çekti. }\end{array}$ & $\begin{array}{l}\text { Görsel ögeleri kul- } \\
\text { lanma } \\
\text { Derse ilgi duyma }\end{array}$ & $\begin{array}{l}\text { Metne } \\
\text { görsel ha- } \\
\text { zırlık }\end{array}$ \\
\hline
\end{tabular}

(*GN= Gözlem Notları. Gözlem notları araştırma boyunca tablolarda "GN" olarak ifade edilmiştir.)

Dinleme öncesine yönelik hazırlanan görsel içerikli materyallerin sürece olumlu etkilerini öğrenci günlüklerindeki ifadeler de desteklemektedir. Öğrenciler günlüklerinde dinleme öncesinde kullanılan görsel unsurların dinleme sürecine etkilerinden bahsetmektedir.

Tablo 5. EP4'te metne görsel hazırlığa yönelik ÖG'den elde edilen veriler

\begin{tabular}{|c|c|c|}
\hline Öğrenci günlüğünden cümleler & Kod & Tema \\
\hline $\begin{array}{l}\text { Ö1: Görseller çok güzel olmuştu, bu yüzden güzel tahminler geldi. Ö3: Metni önceden tah- } \\
\text { min etmek metni daha bir merak içinde dinlememem ve anlamama neden oluyor. Metinden } \\
\text { önceki görseleler güzeldi; çünkü metni daha eğlenceli kıldı. Ö4: Baştaki görseller işime ya- } \\
\text { radı. Etkinliklerdeki yerleri daha rahat yaptım. Ö5: Önceden izletilen video çok güzeldi, tah- } \\
\text { minde ve metni anlamamız konusunda çok yardımcı oldu. Ö6: Metinden önce gördüğüüz } \\
\text { videodaki resimlerden metinle ilgili çok fazla tahminim oldu. Ö7: Resimler hem metni tah- } \\
\text { min etmemize hem de metni merak etmemizi sağladı. Ö8: Metni dinlemeden önce görselleri } \\
\text { göstermeniz güzeldi, daha iyi merak uyandırdı. Ö9: Metni dinlemeden önceki fotoğraf vide- } \\
\text { osu çok güzel oldu. Hep bu video etkinliğini yapalım. Bu etkinlik aklıma daha fazla şeyler } \\
\text { getirdi. Ö10: Etkinlikten önce video izlememiz güzel oldu. Ö12: Resimli metinler yapmaya } \\
\text { devam edin, resimli metinler daha kolay anlamamı sağliyor. Ö14: Çalışma yaprağ1 } 1 \text { çok } \\
\text { güzeldi Ö18: Metni dinlemeden önce gördüğümüz resimler metindeki soruları daha kolay } \\
\text { anlamamız sağlıyor. Ö20: Resimler metni daha kolaylaştırdı. }\end{array}$ & $\begin{array}{l}\text { Sunu kullanma } \\
\text { İlgi çekme } \\
\text { Video izleme } \\
\text { Tahmin etme } \\
\text { Merak duyma } \\
\text { İlgi çekme } \\
\text { Görsel unsurları } \\
\text { kullanma }\end{array}$ & $\begin{array}{c}\text { Metne } \\
\text { görsel } \\
\text { hazırlık }\end{array}$ \\
\hline
\end{tabular}

Tablo 6. EP5'te metne görsel hazırlığa yönelik ÖG'den elde edilen veriler

\begin{tabular}{|c|c|c|}
\hline Öğrenci günlüklerinden cümleler & Kod & Tema \\
\hline $\begin{array}{l}\text { Ö1: İlk izlediğim slayt çok güzeldi slaytta demokrasiyi tam anlamıyla öğrendim. Ö2: Din- } \\
\text { lemeden önceki slayt konuyu anlamamda faydalı oldu. Ö4: Metinleri dinlemeden önce gör- } \\
\text { sel video görmek daha iyi anlamamızı sağlıyor. Ö5: Slayt ve piyes çok güzeldi çalışma yap- } \\
\text { raklarında çok yardımcı oldu. Ö7: Konudan önce slayt olması, konuya geçince "Burada ne } \\
\text { diyor?” diye bakmamı engelliyor. Ö8: Metni dinlemeden önce slayt izlememiz çok iyiydi, } \\
\text { metne hazırlık yaptık. Ö9: Metni dinlemeden önce ve dinlerken slaytlar her zaman olsa iyi } \\
\text { olur. Ö10: Görseller bizim için iyi oldu, metne hazırlandık. Dinlemeden önceki ve dinleme } \\
\text { sırasındaki slaytlar metni anlamama yardımcı oldu. Ö11: Metinlerden önce slaytlar izlemek } \\
\text { metni daha iyi anlamamı sağlıyor. Ö13: Slaytlar güzeldi. Ö18: Piyes yaptık demokrasi ile } \\
\text { ilgili daha bir zevk kattı bence derse, slaytları da sevdim. Ö19: Görseller çok güzeldi. Ö20. } \\
\text { Slaytlar çok bilgi verdi. Ö21: Görseller güzeldi. }\end{array}$ & $\begin{array}{c}\text { Slayt kullanma } \\
\text { Piyes yapma } \\
\text { Görselleştirme } \\
\text { Öğrenciye etki } \\
\text { etme } \\
\text { Piyes yapma }\end{array}$ & $\begin{array}{r}\text { Metne } \\
\text { görsel } \\
\text { hazırlık }\end{array}$ \\
\hline
\end{tabular}

Tablo 7. EP6'da metne görsel hazırlığa yönelik ÖG'den elde edilen veriler

\begin{tabular}{lcc}
\hline Öğrenci günlüklerinden cümleler & Kod & Tema \\
\hline Ö3: Slaytlar metni daha iyi anlamamızı sağladı. Ö4: Slaytlar, görseller ve bilgilendirmeler & & \\
konuyu kavramaya yardımcı oluyor. Ö7: Hazıllı slaytları uygundu. Bize organlarımız hak- & Görsel ögeleri & Metne \\
kında bilmediklerimizi öğretti. Ö9: Metne hazırlık slaytları çok güzel şeyler anlatıyordu. & kullanma & görsel \\
Metin çok güzeldi. Ö10: Metinden önceki slaytlar bizim ççin iyi oluyor. Görseller metni & hazırlık \\
anlamamızı sağladı. Ö11: İki slaytı da çok beğendim. İkisinde de bilmediğim güzel bilgiler & Öğrenciye etki & \\
öğrendim. Ö15: Metinden önce slaytlar izlememiz metni anlamamızı kolaylaştırıyor. Ö20: & etme \\
Slaytlar metni anlamama yardım ediyor. & & \\
\hline
\end{tabular}

Dinleme öncesine yönelik yürütülen uygulamalarda görsel unsurların kullanımının önemli olduğu incelenen gözlem notları, araştırmacı günlüğü ve öğrenci günlüklerinde yer alan ifadelerden anlaşılmaktadır. Ayrıca son görüşme sorularından elde edilen veriler de bu durumu desteklemektedir. 
Tablo 8. Metne hazırlık uygulamalarına yönelik son görüşme formundan elde edilen veriler

Dinleme metnine yönelik olarak dinleme öncesinde yapılan hazırlık bölümünü önceki uygulamalarımızla karşılaştırdığınızda nasıl değerlendiriyorsunuz? (slayt, çalışma yaprağı, resimler vb.)

\begin{tabular}{|c|c|c|}
\hline Öğrenci & Kod & Tema \\
\hline $\begin{array}{l}\text { Ö1, Ö2, Ö4, Ö8, Ö12, Ö13, Ö14, Ö16, Ö18, Ö20, Ö22: Dinleme öncesinde yap1lan ha- } \\
\text { zirlıklar eğlenceli, güzel ve öğreticidir. }\end{array}$ & İlgi çekme & \multirow{3}{*}{$\begin{array}{l}\text { Dinleme ön- } \\
\text { cesi uygula- } \\
\text { maları }\end{array}$} \\
\hline $\begin{array}{l}\text { Ö1, Ö3, Ö5, Ö8, Ö10, Ö11, Ö12, Ö15, Ö17, Ö19, Ö21, Ö23: Metinle ilgili bilgi verince } \\
\text { sorular1 daha iyi yapabiliyorum, anlamam1 kolaylaştırıyor. }\end{array}$ & $\begin{array}{c}\text { Anlamayı ko- } \\
\text { laylaştırma }\end{array}$ & \\
\hline $\begin{array}{l}\text { Ö2, Ö4, Ö6, Ö17: Dinleme öncesi yapılan hazırlık bölüm eskiden iyi değildi. } \\
\text { Ö7, Ö9, Ö11, Ö15, Ö19: Dinleme öncesi görsel materyallerin kullanımı çok faydalı. }\end{array}$ & $\begin{array}{l}\text { Görsel ögele- } \\
\text { rin etkisi }\end{array}$ & \\
\hline
\end{tabular}

Dinleme öncesi yapılan hazırlık uygulamalarının önemi eylem araştırması süresince anlaşılmıştır. Süreç içerisinde metne hazırlık uygulamalarının etkileri fark edildikçe dinleme öncesine yönelik hazırlık uygulamalarının niteliği artırılmıştır. Derse hazırlıkta yer verilen; görsel unsurların, bilgisayar sunularının ve öğrenciyi sürece dâhil edecek uygulamaların öğrenciye katkı sağladığı görülmüștür. Araştırma süresince dinleme metinlerinin niteliğinin dinlediğini anlama başarısında önemli rol oynadığı anlaşılmaktadır. Dinleme metinlerinde; metin türü, metnin seviyeye uygunluğu, metnin içeriği, metnin uzunluğu vb. unsurların dinlediğini anlama başarısına etki ettiği görülmüştür.

Dinleme metinlerinde metinlerin orijinal olmasının önemli olduğu görülmüştür. Öğrencilerin dinleme metnini önceden biliyor olması dinlediğini anlama başarısının ölçümünde objektif sonuçlar alınmamasına neden olmaktadır. Bu nedenle yapılan hazırlık çalışmaları ve seçilen metinlerin metnin orijinalliğine zarar vermemesinin önemli olduğu düşünülmektedir. Yürütülen eylem planı 1'de sözcüklerin anlamının tahmin sürecinde metnin konusunun bilindiğini anlaşılmıştır. Bu durum karşısında metnin bilinip bilinmediği sorgulanmış, öğrencilerin tümü tarafından metnin konusunun bilindiği ancak metnin bilinmediği anlaşılmıştır.

Tablo 9. EP1'de metnin orijinalliğine yönelik AG'den elde edilen veriler

\begin{tabular}{lcc}
\hline Araştırmacı günlüğünden cümleler & Kod & Tema \\
\hline $\begin{array}{l}\text { Dinleme öncesine yönelik yapılan hazırlık çalışmalarında, öğrencilerin dinleme metnini de- } \\
\text { gili; ancak dinleme metnin konusunu bildiğini fark ettim. Seçtiğim metin Türkçe ders kitap- } \\
\text { larında yer alan bir dinleme metniydi. Metnin konusu tarihi gerçeklere dayanıordu. Öğren- } \\
\text { cilerin metni değil ancak konuyu bilmesinin metnin orijinalliğine zarar verdiğini düşünüyo- } \\
\text { rum. 12.02.2018 - s. } 1 .\end{array}$ & $\begin{array}{c}\text { Konuyu } \\
\text { bilme }\end{array}$ & $\begin{array}{c}\text { Metnin ori- } \\
\text { jinalliği }\end{array}$ \\
\hline
\end{tabular}

Seçilen metinlerin öğrencilerin karşılarına ilk kez çıkması önemlidir, ayrıca sadece metin değil işlenecek konunun da orijinalliğini korumasının önemli olduğu düşünülmektedir. Yürütülen 1. Eylem Planı sonrası, çalışma yaprakları incelendiğinde "mebus" sözcüğünün anlamının tahmininde "Ö5: Bence yazarlar yarışmaya şiir katacaklar ya, o şiirlerdir. Ö22: Yarışmaya katılacak aday insanlar olabilir." şeklinde ifadelerle karşılaşılmıştır. Öğrencilere metin ile daha önce karşılaşıp karşılaşılmadığı sorulduğunda, metnin kendisinin bilinmediği ancak konusunun öğrenciler tarafından bilindiği görülmüştür. Bu durumun dinlediğini anlama başarısının objektif değerlendirilememesine ve öğrencinin ilgisini kaybetmesine neden olabileceği düşünülmektedir. Dinleme sürecinde metin türünün önemi anlaşılmıştır. Öğrencilerin metinlerin türüne, metnin içeriğine göre tutum geliştirdikleri görülmüş, bu tutumun da dinleme sürecine etki ettiği fark edilmiştir.

Tablo 10. EP7'de metnin niteliğine yönelik ÖG'den elde edilen veriler

\begin{tabular}{lcc}
\hline Öğrenci günlüklerinden ifadeler & Kod & Tema \\
\hline Ö1: Metin kısa, kolay ve güzeldi. Ö2: Ben eğlenceli ve komik bir metin olduğu için beğendim. & Metnin içeriği & \\
Ö3: Metin kolay ve güzel bir metindi. Ö4: Metin güzeldi. Ö13: Güzel bir metindi. Ö14: Konu & Metnin türü & Metnin \\
çok güzel ve basitti Ö17: Metin güzeldi, komikti beğendim. Ö21: Konu çok eğlenceliydi. Ö22: & niteliği \\
$\begin{array}{l}\text { Eğlenceli bir metindi. Zorlandığım yer yoktu. Ö12: Diyalog yapmaya devam edin, çok güzel } \\
\text { oluyor. Ö14: Türü çok güzeldi. Ö15: Bence tiyatro çok güzeldi, çok eğlendim. Ö18: Metnin } \\
\text { diyaloglar hâlinde olmas1 soruları kolay yapmışt1. Ö7: Seçilen Hacivat Karagöz metinleri de }\end{array}$ & $\begin{array}{c}\text { Seviyeye uy- } \\
\text { yaşımıza uygundu. }\end{array}$ & \\
\hline
\end{tabular}


Tablo 11. EP2'de metnin niteliğine yönelik AG'den elde edilen veriler

\begin{tabular}{lcc}
\hline Araştırmacı günlüğünden cümleler & Kod & Tema \\
\hline Öğrenciler metnin "masal” olduğu ile ilgili tahminleri kesinleşince çok sevindi. Bir öğrenci- & Metin türü & Metnin \\
nin “yaşasın masal dinleyecekmişiz" şeklindeki ifadesi dikkat çekiciydi. Birçok öğrencinin & Güdülenme & niteliği \\
gülümsediğini, derse olumlu duygularla başladığını hissettim. 26.02.2018 - s. 3. & & \\
\hline
\end{tabular}

Tablo 12. EP2'de metin niteliğine yönelik ÖG'den elde edilen veriler

\begin{tabular}{lcc}
\hline Öğrenci günlüklerinden cümleler & Kod & Tema \\
\hline $\begin{array}{l}\text { Ö5: Metin güzeldi, masal olduğu için çok kolay anlaşılıyordu. Ö15: Çok güzeldi çünkü ben } \\
\text { masalları seviyorum. Ö19: Metin çok güzel bir metindi masal olmas1 da ayrıca güzeldi. Ö20: }\end{array}$ & Metin türü & Metnin \\
Metni çok kolay anladım, masalları seviyorum. Ö21: Güzeldi, hiç sıkılmadım. Iyi ki masaldı. & Oggrenci tutumu & niteliği \\
\hline
\end{tabular}

Dinleme metinlerinin türünün dinlediğini anlama başarısında önemli rol oynadığı görülmüş, öğrencilerin olay yazılarını düşünce yazılarına tercih ettiği anlaşılmıştır. Öğrenci günlüklerinde yer alan düşünce türündeki metinlere yönelik ifadeler aşağıdaki tablolarda verilmiştir.

Tablo 13. EP3'te metin niteliğine yönelik ÖG'den elde edilen veriler

\begin{tabular}{|c|c|c|}
\hline Öğrenci günlüklerinden cümleler & Kod & Tema \\
\hline \multirow{5}{*}{$\begin{array}{l}\text { Ö1: Metin çok güzel ama dinlemede makale türü olmamış. Ö2: Tür dinlemeye uygun de- } \\
\text { ğildi. Ö5: Metin bir dinleme metni olmasa güzel bir metin. Dinleme metni için zor bir metin } \\
\text { bu metin dinleme metni değil de kâğıda yazılı olarak yapsalardı daha güzel olurdu. Bence } \\
\text { metin bir makale olduğu için dinleme metni olmamalıyd. Ö9: Bana göre makaleler dinleme } \\
\text { metni olmamalı. Ö13: Makale olduğu için zordu. Ö14: Türünün makale olması ayrı bir } \\
\text { zordu. Bu kadar zor bir metni dinleme metni yapmamalılar. Ö18: Metin biraz ağır olduğu } \\
\text { için etkinlikler zor geldi, türü de makale gibi zor bir türdü. Ö19: Metin çok zordu bir makale } \\
\text { dinleme metni olmamalı. }\end{array}$} & Düşünce yazıları & \multirow{5}{*}{$\begin{array}{l}\text { Metnin } \\
\text { niteliği }\end{array}$} \\
\hline & Metnin türü & \\
\hline & Öğrenci tutumu & \\
\hline & Metnin türü & \\
\hline & Düşünce yazıları & \\
\hline
\end{tabular}

Tablo 14. EP8'de metnin niteliğine yönelik ÖG'den elde edilen veriler

\begin{tabular}{|c|c|c|}
\hline Öğrenci günlüklerinden cümleler & Kod & Tema \\
\hline $\begin{array}{l}\text { Ö1: Öğretici bir metindi. Biraz sıkıcıydı. Ö2: Metin bilgilendiriciydi, sevmiyorum böyle } \\
\text { metinleri. Ö4: Metin düz konuşma olduğu, bir olay olmadığı için biraz zorlandım. Ö7: } \\
\text { Metni dinleme metni için uygun bulmadım. Bence masal hikâye olmalı her zaman. Ö8: } \\
\text { Metni dinlerken insan sıkılıyor ama verdiği bilgiler güzeldi. Ö11: Metni hiç beğenmedim, } \\
\text { çünkü metin röportajdı. Böyle metinleri işlemeyi tercih etmem. Metni anlamadım. Ö12: } \\
\text { Metin zordu, metni anlayamadım. Ö14: Metin fazla resmiydi. Bilgi veriyordu sadece. Ö20: } \\
\text { Metin kötüydü, sıkılıyorum böyle metinlerde. Ö21: Konu bence çok sıkıcıydı, işime yarasa } \\
\text { da sevmiyorum böyle vazıları. Ö22: Metin zordu, keske hep hikâye olsa. }\end{array}$ & $\begin{array}{l}\text { Metnin türü } \\
\text { Metnin türü } \\
\text { Öğrenciye } \\
\text { etki etme }\end{array}$ & $\begin{array}{l}\text { Metnin nite- } \\
\text { liği }\end{array}$ \\
\hline
\end{tabular}

Öğrencilerin düşünce yazısı türünde metinleri dinlemek istemediği anlaşılmaktadır. Ayrıca öğrencilerin düşünce yazılarına karşı ön yargı içerisinde olduğu görülmektedir. Durumu gösteren gözlem notları aşağıda verilmektedir.

Tablo 15. EP3'te metnin niteliğine yönelik GN'den elde edilen veriler

\begin{tabular}{lcc}
\hline Gözlem notları & Kod & Tema \\
\hline Tarih: 08.03.2018 - Saat: 07.30-07-32 & & \\
Öğrenciler türden hiç memnun gibi görünmüyor. Özellikle anahtar kelimelerin açıklanma- & & \\
sindan sonra sınıfta türe yönelik şikâyetler oldu. Ö15: Ögretmenim türü makale olmasaydı & Metnin türü & Metnin nite- \\
keşke. Ö22: Ben anlamam ya bu metni. Ö20: Keşke gene masal dinleseydik anlayamam & liği \\
ki bu metni, dedi. Öğretmen, henüz metnin dinlenmediğini ön yargllı olmamaları gerekti- & Öğrenci tu- & tumu \\
ğini belirtti. Metnin konusunun yeni neslin seveceği uzay, evren, bilim ile ilgili olduğunu & & \\
ifade etti. & &
\end{tabular}

Dinleme metinlerinde, metnin türünün önemli bir unsur olduğu anlaşılmıştır. Dinleme metninin türü kadar metnin uzunluğu da önemli bir faktördür. Dinleme metinlerinde metnin uzunluğunun göz önüne alınarak dinleme sayısının belirlenmesinin önemi eylem sürecinde fark edilmiştir. 
Tablo 16. EP2'de metnin niteliği ve dinleme sayısına yönelik ÖG'den elde edilen veriler

\begin{tabular}{lcc}
\hline Öğrenci günlüklerinden cümleler & Kod & Tema \\
\hline Ö1: Metin güzeldi, sıkııı değildi. Metin uzun olduğu için üç kere dinlenebilirdi. Ö9: Metni 3 & & \\
kere dinleyebilirdik. Ö10: Metin uzundu, uzun olduğu için yoruldum, anlayamadım. Ö12: Me- & Metnin uzun- & Metnin \\
tin çok uzundu 3 kere dinleseydik daha iyi olurdu. Ö13: Metni 3 kere dinleyebilirdik. Akılda & luğu & niteliği \\
kalıcı olmasına rağmen fazla uzundu. Uzun olduğundan bir yerinde metinden kopuyoruz. Ö18: & Metin-dinleme & Dinleme \\
$\begin{array}{l}\text { Metin uzun olduğu için aklımızda kurgulayamadık. Daha iyi anlamamız için 3 veya 4 kere } \\
\text { dinlesek iyi olurdu. }\end{array}$ & sayısı uyumu & sayısı \\
\hline
\end{tabular}

Araştırmada yürütülen eylem planı sonrası öğrencilerin dinlediğini anlama başarısını belirlemeye yönelik sorular sorulmuştur. Cevaplar incelendiğinde, öğrencilerin ayrıntı içeren soruları yanlış yaptığı ve yanlış cevapların metninin son bölümlerinde yoğunlaştığı görülmüştür. Yanlış cevapların nedenleri araştırıldığında metnin niteliğine uygun dinleme sayısının önemi fark edilmiştir. Dinleme metinlerinin türü ve uzunluğu kadar dikkat çeken bir diğer unsur metinlerde yer alan ilk kez karşılaşılan sözcük sayısının miktarıdır. Yürütülen ilk eylem planında ortaokul 6. sınıf Türkçe ders kitabında yer alan bir dinleme metni kullanılmıştır. Uygulama sonrası incelenen çalışma yapraklarında öğrencilerin yanlışlarının belli noktalara toplandığı fark edilmiştir. Öğrencilerin ilk kez karşılaşılan sözcüklerin fazla olduğu paragraflara yönelik soruları cevaplayamadığı görülmüştür. Ayrıca incelenen öğrenci günlüklerindeki ifadelerden de ilk kez karşılaşılan sözcük miktarının önemi anlaşılmıştır.

Tablo 17. EP1'de sözcük bilgisine yönelik ÖG'den elde edilen veriler

\begin{tabular}{lcc}
\hline Öğrenci günlüklerinden cümleler & Kod & Tema \\
\hline Ö2: Metinde çok bilinmeyen kelime var. Ö4: Dinleme metinlerinde, karışıklık, fazla tarih ve bil- & \\
mediğimiz kelimeler olmamalı. Ö7: Metinde çok fazla bilinmeyen kelime vardı. Biz tarihimizi & Sözcük \\
bildiğimiz için bilinmeyen kelimeleri anlamaya çalıştı. Ama bizim tarihimizi bilmeyen bir kişi & anlamı \\
anlamayabilirdi. Ö13: Bilmediğim yabancı kelimel çoktu, kötüydü çünkü çok zordu. Ö14: Bi- & bilme & Sözcük \\
linmeyen kelimeler yüzünden metni anlamakta zorlandım. Ö15: Metinde anlamadığım kelime & Bilinen & bilgisi \\
biraz fazlaydı. Ö17: Bu metinde bilmediğim birçok kelime vardı. Ö18: Çok fazla bilinmeyen ke- & sözcük \\
lime vardı. Ö20: Çok fazla eski kelime vardı, bir dahaki metinde inşallah eski kelime olmaz. Ö22: & sayısı \\
Metinde çok bilinmeyen kelime vardı. Zaten bana göre en zor yer de bilinmeyen kelimelerdi. & \\
\hline
\end{tabular}

Tablo 18. EP1'de sözcük bilgisine yönelik AG'den elde edilen veriler

\begin{tabular}{|c|c|c|}
\hline Araştırmacı günlüğünden cümleler & Kod & Tema \\
\hline $\begin{array}{l}\text { Çalışma yaprağı } 3 \text { cevaplandırılırken derse katılımın yetersiz olduğunu fark ettim. Öğrencilerde } \\
\text { dinleme öncesi ve dinleme sırasındaki isteklilik kalmamış gibi görünüyordu. Metni anladığını } \\
\text { düşündüğüm öğrencilerin bile parmak kaldırmakta kararsız oldukları gördüm. Bu durum sebe- } \\
\text { binin ilk kez karşılaşılan sözcüklerin sayısının fazla olması olduğu kanaatindeyim. Çünkü öğ- } \\
\text { renciler ders içerisinde ve hatta teneffüste bu durumdan şikâyetçi olduklarını sık sık dile getirdi. } \\
\text { Sözcük bilgisinden kaynaklanacak eksiklikleri engellemeye yönelik yapılan dinleme öncesi uy- } \\
\text { gulamalara rağmen, öğrencilerin sözcüklerin anlamlarını içselleştiremedikleri için metni anla- } \\
\text { makta zorluk çektiğini düşünüyorum. } 12.02 .2018-\text { s. } 2 \text {. }\end{array}$ & $\begin{array}{c}\text { İlgi } \\
\text { duyma } \\
\text { Bilinen } \\
\text { sözcük sa- } \\
\text { y1sı }\end{array}$ & $\begin{array}{l}\text { Sözcük } \\
\text { bilgisi }\end{array}$ \\
\hline
\end{tabular}

Yürütülen uygulamalar sonrası dinleme metinlerinin niteliğinin dinleme sürecinde rol oynadığı fark edilmiştir. Seçilen dinleme metinlerinde tür, uzunluk ve anlamı ile ilk kez karşılaşılan sözcük miktarının önemli olduğu ve dinleme sürecine etki ettiği anlaşılmıştır. Araştırma süresince dinleme metinlerinin niteliğinin yanı sıra ses dosyalarının niteliğinin de önemi fark edilmiştir. Uygulamalara internet bağlantısı üzerinden ulaşılan hazır ses dosyaları ile başlanmış, ancak ilerleyen uygulamalarda hazır ses dosyalarında seslendirmelerde eksiklikler olduğu görülmüştür.

Tablo 19. EP3’te ses dosyalarının niteliğine yönelik ÖG'den elde edilen veriler

\begin{tabular}{|c|c|c|}
\hline Öğrenci günlüklerinden cümleler & Kod & Tema \\
\hline $\begin{array}{l}\text { Ö2: Çalışma yaprağını 2'de birini yazarken diğerini yazmaya çalıştım çok hızlıydı, ye- } \\
\text { tişemedim. Bu yüzden de dinleme akılda kalıcı değildi. Ö6: Metni anlamamamın sebebi } \\
\text { hızlı okunmasıydı. Ö9: Metni okuyan kişi çok hızlı okudu biz de anlayamadık, bu yüz- } \\
\text { den bazı yerleri kaçırdı. Ö10: Metni okuyan çok hızlı okuduğu için metni anlamamız } \\
\text { zor oldu. Ö13: Okuyucunun hızı biraz daha yavaş olabilirdi. Çok hızlı okuyordu. Ö17: } \\
\text { Dinleme metni olmasına rağmen okuyan kişi çok hızlı okuyordu o yüzden anlayamadım. } \\
\text { Bazı yerleri kaçırdım. Ö21: Dinleme metni çok hızlı geçiyordu, o yüzden biraz anlamak } \\
\text { zor oldu. Ö23: Metni dinlerken çok zorlandık, zorlanmamızın sebebi metnin okuyucusu } \\
\text { çok hızlı okuyordu. }\end{array}$ & $\begin{array}{l}\text { Metnin anlaşı- } \\
\text { labilirliği } \\
\text { Okuyucu hızı }\end{array}$ & $\begin{array}{l}\text { Ses dosyala- } \\
\text { rının niteliği }\end{array}$ \\
\hline
\end{tabular}


Eylem planı hazırlanırken bu metin için okuyucu hızı araştırmacı tarafından fark edilmemiştir. Ancak öğrenci günlüklerinin incelenmesi sonucu durum ortaya çıkmıştır. Bu sebeple araştırmacı 4, 5 ve 6. eylem planlarında kullanılan metinleri kendi seslendirmiştir. Araştırmacının sınıf seviyesine uygun hızda, vurgu ve tonlamalara dikkat ederek, uygun fon müzikleri ile seslendirdiği dinleme metinleri öğrencilerin dikkatini çekmiş, dinleme sürecini olumlu etkilemiştir.

Tablo 20. EP4'te ses dosyalarının niteliğine yönelik ÖG'den elde edilen veriler

\begin{tabular}{|c|c|c|}
\hline Öğrenci günlüğünden cümleler & Kod & Tema \\
\hline $\begin{array}{l}\text { Ö4: Metni sizin okumanız başta tuhaftı ama sonra alıştık. Okumanız vurgularınız çok gü- } \\
\text { zeldi. Ö5: Bu sefer okuma ile ilgili sıkıntı yoktu. Diğer metinlerde olduğu gibi ne yavaş ne } \\
\text { hızlıydı. Ö7: Öğretmenimizin seslendirmesi bana cazip geldi, hoşuma gitti. Ö8: Metni ses- } \\
\text { lendirmeniz güzeldi, daha iyi anladık. Ö11: Hocamızın okuduğunu görünce önce çok şaşır- } \\
\text { dım, ama diğer okurlardan daha iyi okuyor. Ö12: Metni sizin seslendirmeniz güzel olmuş. } \\
\text { Ö18: Siz seslendirdiğiniz için iyi olmuș. }\end{array}$ & $\begin{array}{l}\text { Vurgulama } \\
\text { Okuyucu hızı } \\
\text { Seslendirme }\end{array}$ & $\begin{array}{l}\text { Ses dosyalar1- } \\
\text { nın niteliği }\end{array}$ \\
\hline
\end{tabular}

Uygulamalarda nitelikli ses dosyalarının öneminin fark edilmesinin ardından 5 ve 6. eylem planları için araştırmacı tarafından hazırlanan ses dosyalarına görsel ögeler ve fon müziği eklenmiştir. Kullanılan görsel ve işitsel materyallerde metnin niteliği, içeriği, öğrenci seviyesi vb. unsurlara özen gösterilmeye çalış1lmıştır. Görsel ve işitsel unsurlarla zenginleştirilerek yürütülen uygulamaların dinleme sürecine etki ettiği görülmüştür.

Tablo 21. EP5'te ses dosyalarının niteliği yönelik ÖG'den elde edilen veriler

\begin{tabular}{|c|c|c|}
\hline Öğrenci günlüklerinden cümleler & Kod & Tema \\
\hline \multirow{3}{*}{$\begin{array}{l}\text { Ö3: Slaytlardaki resimler metni anlamama çok yardımcı oldu. Ö5: Metni dinleme s1- } \\
\text { rasındaki slayt da çok güzeldi. Çalışma yapraklarında yardımcı oldu. Ö9: Metni din- } \\
\text { lemeden önce ve dinlerken her zaman slayt olsa iyi olur. Ö10: Dinlemeden önceki ve } \\
\text { dinleme anındaki slaytlar metni anlamama yardımcı oldu. Ö15: Görseller çok güzeldi } \\
\text { ve şiirdeki kıtalarla uyuşuyordu. Etkinlikler çok güzeldi. Ö16: Görseller çok açklay1- } \\
\text { cıyd1. Ö18: Resimler şiirle uyuşmuştu. Ö19: Bir de görseller çok güzeldi. Ö21: Gör- } \\
\text { seller güzeldi. }\end{array}$} & $\begin{array}{l}\text { Görsel destekli } \\
\text { dinleme metni }\end{array}$ & \multirow{3}{*}{$\begin{array}{l}\text { Ses dosyaları- } \\
\text { nın niteliği }\end{array}$} \\
\hline & $\begin{array}{c}\text { Öğrenciye etki } \\
\text { etme }\end{array}$ & \\
\hline & $\begin{array}{l}\text { Görsel destekli } \\
\text { dinleme metni }\end{array}$ & \\
\hline
\end{tabular}

Tablo 22. EP6'da ses dosyalarının niteliğine yönelik ÖG'den elde edilen veriler

\begin{tabular}{lcc}
\hline Öğrenci günlüklerinden cümleler & Kod & Tema \\
\hline Ö1: Metni dinlerken görsellerin olması metni daha anlaşılır ve güzel yaptı. Ö2: Gör- & Görsel ögeleri \\
sellerin olması metni hatırlamamızı kolaylaştırıyor bence. Ö4: Görsellerle metni din- & kullanma & Ses dosyaları- \\
lemek güzel oldu. Ö5: Resimler metni anlamamızı kolaylaştırdı. Ö12: Videoların gör- & Video kullanma & nın niteliği \\
selli olması çok hoşuma gitti. Ö15: Görseller metinle çok uyuyordu. Çok hoşuma gitti. & Ö19: Slaytlar çok güzeldi. Bir de slaytlarda yapılan görseller sayesinde konular ak- & Slayt kullanma \\
lımda kaldı. & & \\
\hline
\end{tabular}

Ses dosyalarında görsel ögelere yer verilmesinin dinleme sürecine etkilerinin fark edilmesinin ardından 7 ve 8. eylem planında dinleme metni ses dosyaları videolarla desteklenmiştir. Metnin niteliğine göre dinleme metninin sınıfa sunuluş şeklinin (ses dosyası, görsel destekli ses dosyası, video kaydı, misafir seslendirici vb.) belirlenmesinin dinlediğini anlama başarısına etki ettiği görülmüştür.

7. eylem planında araştırmacı tarafından perde gösterisi hazırlatılarak videoya alınmıştır. 8. eylem planında yer alan radyo röportajı; radyo ortamında gerçek spikerler tarafından seslendirilerek videoya alınmıştır. Hazırlanan son eylem planında sınıfa misafir bir seslendirici getirilmiştir. Konuşmacıya dinleme metni önceden verilerek hazırlanması sağlanmıştır.

Son eylem planında öğrencilerin ön yargılı ve işlemekte isteksiz olduğu düşünce yazısı türünde bir metin seçilmiştir. Yürütülen uygulamalar sonrası metnin niteliğine uygun şekilde metnin sınıfa sunulmasının dinleme sürecine etki ettiği anlaşılmıştır.

Dinleme metinlerinde dinleme stillerinin belirlenmesinde, metnin niteliğinin ve metnin sınıfa sunuluş şeklinin önemli olduğu düşünülmektedir. Yürütülen araştırmada dinleme stilleri, metnin niteliğine ve metnin sinıfa sunuluş şekline göre belirlenmiştir. Süreç içerisinde öğrencilerin derse aktif katılımı sağlanmıştır. Öğrenciler sürecin bir parçası olarak kendilerini gördükleri için olumlu duygularla dersi tamamlamışlardır. 
Tablo 23. EP9'da metnin niteliği, metnin sunuluşu, dinleme stili sınıf içi ortama yönelik ÖG'den elde edilen veriler

\begin{tabular}{|c|c|c|}
\hline Öğrenci günlüklerinden cümleler & Kod & Tema \\
\hline $\begin{array}{l}\text { Ö1: Makale zor bir tür ama konuşarak dersi işlediğimiz için zevkli oldu. Ö2: Bugün ma- } \\
\text { kale işleyeceğimizi duyunca herkes üzüldü; ama hocalarımızın anlatım şeklinden dolay1 } \\
\text { çok iyi geçti. Anlayarak öğrendik. Ö3: Metnin türü makale olduğu için biraz zordu. Diğer } \\
\text { hoca ile konuşarak işlememiz sayesinde metni anlamam kolaylaştı. Eğer metni bu şekilde } \\
\text { işlemeseydik makaleyi anlayamazdı. Ö4: Başka bir öğretmenin anlatması güzeldi. Ders } \\
\text { eğlenceliydi. Tür makale olduğu için biraz zorlanacağımızı düşünmüştüm ama aralarda } \\
\text { konuşa konuşa açılayarak gittiğimiz için net bir şekilde anladım. Ö5: Metnin türü makale } \\
\text { idi. Makaleyi böyle işlemek anlamamızı kolaylaştırdı. Ö7: Metnin türü makale olduğu için } \\
\text { anlaması zor gibi olurdu ama daha güzel işlediğimiz için anladık. Etkinlikler de güzeldi. } \\
\text { Ne çok zor ne çok kolaydı. Metin gelen olarak güzeldi. Ö8: Metin biraz zordu ama çok } \\
\text { eğlenceliydi. Ö9: Ders işleyişi eğlenceli olduğu için derse katılım çok oldu. Ö10: Makale } \\
\text { sıkıcıydı ama etkinlik yapınca eğlendik, böyle olmasaydı metni çok sıkıc1 işlerdik. Makale } \\
\text { eğlenceli geçti Ö11: Metin makaleydi, makaleleri zor anlıoruz ama bugünkü eğlenceli } \\
\text { işleyişimiz metni kolayca anlamamızı sağladı. Ö15: Makaleyi hiç sevmiyordum ve eğlen- } \\
\text { celi bulmuyordum ama bugünkü dinleme metni çok eğlenceli geçti. Etkinlikler çok güzeldi } \\
\text { ve çok eğlenceli geçti. Sınıfın hepsi katıldı. Ö17: Metnin türü makaleydi ama konuşa ko- } \\
\text { nuşa metnin zorluğunu geçirdik. Genel olarak zor değildi, hocalarımızın işleyişini beğen- } \\
\text { dim, bunun sonucunda daha iyi anladım. Ö19: İlk defa bir makaleyi eğlenerek ve anlayarak } \\
\text { yaptım. Bunun nedeni hocamızla konuşarak işlemekti. Ö21: Eskiden türü makale olan me- } \\
\text { tinlerde açıçası biraz sıkılıyordum ama bu metinde sıkılmadım. }\end{array}$ & $\begin{array}{l}\text { Metin türü } \\
\text { Misafir seslen- } \\
\text { dirici kullanma } \\
\text { Katılımlı din- } \\
\text { leme } \\
\text { Metin-stil } \\
\text { uyumu } \\
\text { Öğrenci katılımı } \\
\text { Katılımlı din- } \\
\text { leme } \\
\text { Metin-stil } \\
\text { uyumu } \\
\text { Katılımlı din- } \\
\text { leme } \\
\text { Öğrenci katılımı }\end{array}$ & $\begin{array}{c}\text { Metnin } \\
\text { niteliği } \\
\text { Metnin } \\
\text { sunuluşu } \\
\text { Dinleme } \\
\text { stili } \\
\text { Sınıf içi } \\
\text { ortam } \\
\text { Dinleme } \\
\text { stili } \\
\text { Dinleme } \\
\text { stili } \\
\text { Sinıf içi } \\
\text { ortam }\end{array}$ \\
\hline
\end{tabular}

Tablo 24. EP2'de dinleme stiline yönelik AG'den elde edilen veriler

\begin{tabular}{lcc}
\hline Araştırmacı günlüğünden cümleler & Kod & Tema \\
\hline $\begin{array}{l}\text { Dinleme metni masal türünde uzun bir metin, öğrencilerin masalı dinlerken kafalarını } \\
\text { sıraya koymalarını isteyeceğim. Bu şekilde dinleme anında metnin türüne uygun şekilde } \\
\text { davranarak gerçek bir masal dinliyormuş gibi olacaklarını düşünüyorum. 26.02.2018 - } \\
\text { s. 3. }\end{array}$ & Metnin türü & Dinleme \\
stili
\end{tabular}

Tablo 25. EP3'te dinleme stiline yönelik AG'den elde edilen veriler

\begin{tabular}{|c|c|c|}
\hline Araştırmacı günlügünden cümleler & Kod & Tema \\
\hline $\begin{array}{l}\text { Seçilen dinleme stili öğrencilerin dinlediklerini anlamalarına etki ettiğini fark ettim. Seçilen din- } \\
\text { leme stili dinleme metninin niteliğine göre ayarlanması, dinlenilecek metnin anlaşılmasında rol } \\
\text { oynamaktadır. Metin türü ve dinleme stilinin korelasyon içerisinde olmasına dikkat edilerek eylem } \\
\text { planlarının oluşturulmasının dinlediğini anlama başarısına etki edeceğini düşünüyorum. } \\
\text { 08.03.2018 - s. } 5 \text {. }\end{array}$ & $\begin{array}{l}\text { Dinleme } \\
\text { stili seçme } \\
\text { Metin-stil } \\
\text { uyumu }\end{array}$ & $\begin{array}{c}\text { Dinleme } \\
\text { stili }\end{array}$ \\
\hline
\end{tabular}

Tablo 26. EP4'te dinleme stiline yönelik AG'den elde edilen veriler

\begin{tabular}{|c|c|c|}
\hline Araştırmacı günlüğü & Kod & Tema \\
\hline $\begin{array}{l}\text {... Ayrıca metinde kahramanlar bir macera yaşıyorlar. Bu maceranın gelişimininin öğrenciler tara- } \\
\text { findan yapılması etkili olabilir. Bu sebeple metnin tahmin ederek dinlenmesi dinlediğini anlama } \\
\text { bașarısına katkı sağlayabilir. 22. } 03.2018-\text { s. } 7 \text {. }\end{array}$ & $\begin{array}{l}\text { Metin-stil } \\
\text { uyumu }\end{array}$ & $\begin{array}{l}\text { Dinleme } \\
\text { stili }\end{array}$ \\
\hline
\end{tabular}

Dinleme sırasına yönelik yürütülen uygulamaların niteliği dinlediğini anlama başarısına etki etmektedir. Bu nedenle ortaokul düzeyinde dinleme metinlerinin niteliğine, metinlerin sınıfa sunuluş şekline ve dinleme stillerine yönelik uygulamalara özen gösterilmesinin önemli olduğu düşünülmektedir. Araştırmada yürütülen uygulamalar sürece olumlu katkı sağlamıştır. Öğrencilerle yapılan son görüşme formunda yer alan cevaplar bu durumu desteklemektedir.

Son görüşme formlarından elde edilen veriler dinleme sürecindeki uygulamaların önceki uygulamalardan daha çok ilgi çektiğini göstermektedir. Ayrıca formdaki öğrenci cevaplarında görsel unsurların dinleme sırasında kullanılmasının etkilerine dikkat çekildiği görülmektedir. Dinleme sürecinde görsel unsurların kullanımı dinleme sürecine etki etmektedir. Yürütülen eylem araştırmasında, dinlediğini anlama başarısının ölçümünde çalışma yaprakları kullanılmıştır. Çalışma yaprakları dinleme sürecinin her basamağında etkili olarak yer almıştır. Dinlediğini anlama başarısının ölçümünde ayrıca ürün oluşturma uygulamalarına yer verilmiştir. Ürün oluşturma uygulamaları, öğrencilerin dinlediklerini içselleştirmesine olanak sağlamıştır 
Tablo 27. Dinleme sırası uygulamalarına yönelik son görüşme formlarından elde edilen veriler

Dinleme sırasındaki uygulamaları önceki uygulamalarınızla karşılaştırdığınızda nasıl değerlendiriyorsunuz? (dinleme stratejileri, çalışma yaprakları, dinleme sayısı, görsel materyaller, dinleme-izleme videoları vb. )

\begin{tabular}{|c|c|c|}
\hline Öğrenci & Kod & Tema \\
\hline $\begin{array}{l}\text { Ö1, Ö4, Ö7, Ö8, Ö10, Ö13, Ö14, Ö16, Ö17, Ö18, Ö20, Ö22, Ö23: Yap1lan uygula- } \\
\text { malar daha eğlenceli ve derse kat1lımımıza büyük etki sağlıyor. }\end{array}$ & İlgi çekme & \multirow{6}{*}{$\begin{array}{r}\text { Dinleme siras } 1 \\
\text { uygulamalar1 }\end{array}$} \\
\hline Ö10, Ö12: Dinleme metinlerine yönelik bakış açım değişti. & \multirow{2}{*}{$\begin{array}{l}\text { Etkinliklerin ni- } \\
\text { teliği }\end{array}$} & \\
\hline Ö2, Ö3, Ö6, Ö11, Ö19: Önceki uygulamalarda kitaplarda yer alan sorular metni din- & & \\
\hline Ö5, Ö9, Ö11, Ö13, Ö14, Ö18, Ö21: Görsel ögelerin kullanımı metni anlamamıza & $\begin{array}{l}\text { Görsel ögelerin } \\
\text { etkisi }\end{array}$ & \\
\hline etki ediyor. & \multirow{2}{*}{$\begin{array}{l}\text { Metin-dinleme } \\
\text { say1s1 uyumu }\end{array}$} & \\
\hline $\begin{array}{l}\text { Ö15: Yeni ders işleniş şeklinde metni dinleme sayısı metni anlamak için yeterli ola- } \\
\text { cak şekilde ayarlanıordu. }\end{array}$ & & \\
\hline
\end{tabular}

Tablo 28. EP5'te ürün oluşturmaya yönelik ÖG'den elde edilen veriler

\begin{tabular}{lcc}
\hline Öğrenci günlüklerinden cümleler & Kod & Tema \\
\hline $\begin{array}{l}\text { Ö4: Şiir yazmak güzel oldu. Ö5: Dörtlük yazmamız hem eğlenceli hem de güzel bir } \\
\text { etkinlikti. Ö6: Etkinlik şiir sevgimi artırdı. Ö9: Şiir yazma etkinliği çok faydalıydı }\end{array}$ & $\begin{array}{c}\text { Öğrenilenlerin } \\
\text { içselleştirilmesi }\end{array}$ & Ürün oluşturma \\
$\begin{array}{l}\text { bence. Ö11: Metnin son etkinliğinde şiir yazmamız çok hoşuma gitti Ö19: Çalışma } \\
\text { yaprağında şiir yazmak çok hoştu. Ö18: Metinde şiir yazdık. Çok hoşuma gitti. }\end{array}$ & $\begin{array}{c}\text { Öğrenci mem- } \\
\text { nuniyeti }\end{array}$ & $\begin{array}{c}\text { etkililiği } \\
\text { etramaların }\end{array}$ \\
\hline
\end{tabular}

Tablo 29. EP7'de ürün oluşturma ve uygulamaların etkililiği yönelik ÖG'den elde edilen veriler

\begin{tabular}{|c|c|c|}
\hline Öğrenci günlüklerinden cümleler & Kod & Tema \\
\hline $\begin{array}{l}\text { Ö1: En son yaptığımız etkinlik çok güzeldi. Ö2: Boyamak çok eğlenceliydi, yazı } \\
\text { yazmak da öyle. Ö3: Çok beğendim özellikle son etkinliği. Ö4: Diyalog yazma gü- } \\
\text { zeldi. Ö5: Perde gösterisi yazmak çok eğlenceliydi, hazırladığım gösterinin perde- } \\
\text { sini boyamaktan da çok zevk aldım. Ö7: Kendimizin yazdığ1 etkinlik güzeldi. Ö8: } \\
\text { Çalışma yaprağ1 3’ün son bölümü çok güzeldi. Eğlenceli bir bitiş oldu. Ö18: Özel- } \\
\text { likle bir diyalog da bizim yazmamız çok güzel oldu. Her zaman buna benzer şeyler } \\
\text { yapabiliriz. Ö19: Son ekinliği çok beğendim. }\end{array}$ & $\begin{array}{l}\text { Metni içselleş- } \\
\text { tirme } \\
\text { Diyalog yazma } \\
\text { Öğrenci memnu- } \\
\quad \text { niyeti }\end{array}$ & $\begin{array}{l}\begin{array}{l}\text { Ürün Oluş- } \\
\text { turma }\end{array} \\
\text { Uygulamaların } \\
\text { Etkililiği }\end{array}$ \\
\hline
\end{tabular}

Tablo 30. EP9' da sınıf içi ortam ve ürün oluşturmaya yönelik GN'den elde edilen veriler

\begin{tabular}{|c|c|c|}
\hline Gözlem notları & Kod & Tema \\
\hline \multicolumn{3}{|l|}{ Tarih: 04.06.2018 - Saat: 09.50-10.00 } \\
\hline $\begin{array}{l}\text { Araştırmacı öğretmen derse büyük bir kutuyla girdi, öğrencilere sürprizin açıklanma } \\
\text { vaktinin geldiğini söyledi. Bayrak alan öğrenciler ellerinde bayraklarla bekliyordu. } \\
\text { Öğretmen: Atık günü }{ }^{1} \text { yapıyoruz, dedi. Öğrenciler havaya zıpladı, alkışlamaya baş- }\end{array}$ & Öğrenci tutumu & Sınıf içi ortam \\
\hline $\begin{array}{l}\text { ladı. Öğretmen: Evet atık malzemeleri ben getirdim. Şimdi aklınızdan millî değerle- } \\
\text { rimize yönelik bir mesaj oluşturuyorsunuz ve bu mesajı atık malzemelerle oluştur- } \\
\text { duğunuz üç boyutlu ürünün üstüne yerleştiriyorsunuz. Öğretmeninizin sorduğu so- } \\
\text { rulara doğru cevap vererek bayrak alanlar, siz bayraklarınızı ürününüzün üzerinde } \\
\text { kullanabilirsiniz. Öğrencilerin sevinçleri yüzlerinden okunuyordu. }\end{array}$ & $\begin{array}{l}\text { At1k malzeme } \\
\text { kullanımı }\end{array}$ & Ürün oluşturma \\
\hline
\end{tabular}

Uygulamalar sırasında öğrencilerin ürün oluşturması kadar oluşturdukları ürünlerin sınıfa sunmasının da önemi fark edilmiştir. Bu nedenle uygulamalarda öğrencilerin yaptıkları çalışmaları arkadaşlarıyla paylaşabilmesi için zamanlama faktörüne dikkat edilmesinin gereği anlaşılmıştır. Uygulamalarda yer verilen etkinliklerin, soruların vb. süre dikkate alınarak planlanması gerekmektedir.

\footnotetext{
${ }^{1}$ Öğrencilerin yaratıcılığını ve sınıf içi etkileşimi artırabilmek için okul içerisinde, belirlenen konu çerçevesinde dersleri aksatmayacak şekilde düzenlenen, öğretmen tarafından adı koyulan bir uygulamadır (Ayrıntılı bilgi için bkz. Göçer, 2016, s. 195-196). 
Tablo 31. EP5'te ürün oluşturma, sınıf içi ortam ve zamanlama faktörüne yönelik GN'den elde edilen veriler

\begin{tabular}{lcc}
\hline Gözlem notları & Kod & Tema \\
\hline Tarih: 02.04.2018 - Saat: 09.30-09.35 & Ürün oluş- \\
turma
\end{tabular}

Tablo 32. EP6'da ürün oluşturma ve zamanlama faktörüne yönelik GN'den elde edilen veriler

\begin{tabular}{|c|c|c|}
\hline Gözlem notları & Kod & Tema \\
\hline Tarih: 16.04. 2018 - Saat: 09.35-09.40 & Metni içselleş- & Ürün Oluş- \\
\hline $\begin{array}{l}\text { Öğrencilere öğretmen dersin sonunda bir dahaki derse mektup yazacakları, yazdıkları } \\
\text { mektupları sınıf içinde okuyacakları söyledi. Ö5:Bu sefer ben okuyayım ilk öğretmenim, } \\
\text { geçen sefer çok güzel yazdım okutmadınız. Ö18:Ben de güzel yazmıştım, dedi. Sınıfta } \\
\text { şiirlerin okunmamasılyla ilgili bir uğultu oluştu. }\end{array}$ & $\begin{array}{l}\text { Zamanı doğru } \\
\text { kullanma }\end{array}$ & $\begin{array}{l}\text { turma } \\
\text { Zamanlama } \\
\text { Faktörü }\end{array}$ \\
\hline
\end{tabular}

Süreç içerisinde ürün oluşturma uygulamalarında bulunulması, öğrencilerin dinlediklerini içselleştirmesine katkı sağlamıştır. Bu tür uygulamaların öğrencilerin öğrenmelerine ve gelişimine etki ettiği anlaşılmıştır. Bu sebeple dersler planlanırken öğrencilerin birbirleriyle iletişime geçebilecekleri uygulamaların kullanımına yer verilmesinin faydalı olabileceği düşünülmektedir.

Dinlediğini ölçme başarısının belirlenmesinde tamamlayıcı ölçme değerlendirme araçlarından faydalanılmıştir.

Tablo 33. EP7'de ürün oluşturma ve tamamlayıcı ölçme değerlendirmeye yönelik GN'den elde edilen veriler

\begin{tabular}{|c|c|c|}
\hline Gözlem notları & Kod & Tema \\
\hline Tarih: 30.04 .2018 - Saat: 09.50-09.55 & & Ürün oluş- \\
\hline $\begin{array}{l}\text { Öğrencilere içerisinde gösteri perdesi olan bir kâğıt dağıtıldı ve öğrencilerden metinle } \\
\text { ilişkilendirerek bir Karagöz-Hacivat metni yazmaları istendi. Ölçütler tahtaya yazıldı. } \\
\text { Metin yazıldıktan sonra, yazan arkadaşlar dinlenirken arkadaki perdeyi istedikleri gibi } \\
\text { boyayabilecekleri söylendi. Ö5: Boya fark eder mi, ne boyası olduğu? Öğretmen: Fark } \\
\text { etmez, dedi. Öğrencilerin değerlendirme ölçütlerini önceden duyurulmasına yönelik } \\
\text { memnuniyetleri anlaşllıyordu }\end{array}$ & $\begin{array}{l}\text { Dinlediklerini iç- } \\
\text { selleştirme } \\
\text { Kaba değerlen- } \\
\text { dirme formu }\end{array}$ & $\begin{array}{l}\text { turma } \\
\text { Tamamla- } \\
\text { y1cı ölçme } \\
\text { değerlen- } \\
\text { dirme }\end{array}$ \\
\hline
\end{tabular}

Tablo 34. EP8'de ürün oluşturma ve tamamlayıcı ölçme değerlendirmeye yönelik GN'den elde edilen veriler

\begin{tabular}{|c|c|c|}
\hline Gözlem notları & Kod & Tema \\
\hline Tarih: 14.05.2018 - Saat: 09.55-10.00 & & \\
\hline $\begin{array}{l}\text { Öğrencilerden yaptıkları afişleri kendilerinin değerlendirmesi istenerek, öz değerlen- } \\
\text { dirme formları dağıtıldı. Öğretmen, öz değerlendirmenin nasıl yapılacağından, öğren- } \\
\text { ciye ne gibi katkıları olduğundan bahsetti. Süreç içerisinde kendini değerlendirmeye alı- } \\
\text { şı olmayan öğrenciler, önce şaşırdı ardından bir ellerine afişi bir ellerine formu alarak } \\
\text { değerlendirmeye başladı. Öğretmen: Arkadaşlar değerlendirmenizde objektif olunuz, } \\
\text { dedi. Ö6: Ö9 beni değerlendirsin, ben de onu olmaz mı, dedi. Öğretmen öz değerlendir- } \\
\text { mede kişinin kendini değerlendirmesi gerektiğini belirterek, objektif olmanın sürece kat- } \\
\text { kısından tekrar bahsetti. }\end{array}$ & $\begin{array}{l}\text { Afiş hazırlama } \\
\text { Öz değerlen- } \\
\text { dirme yapma }\end{array}$ & $\begin{array}{l}\text { Ürün oluş- } \\
\text { turma } \\
\text { Tamamla- } \\
\text { y1cı ölçme } \\
\text { değerlen- } \\
\text { dirme }\end{array}$ \\
\hline
\end{tabular}

Öğrencilerin tamamlayıcı ölçme değerlendirme araçlarından biri olan öz değerlendirme formlarındaki ifadeleri ile ortaya çıkan ürünler karşılaştırılarak incelenmiştir. Öğrencilerin ürün ve süreç konusunda eksik oldukları alanları belirleyebildiği görülmüştür. Öğrencilerin objektif olarak kendini değerlendirebilmesinin eğitim açısından değerli olduğu düşünülmektedir. 
Tablo 35. Dinleme sonrası uygulamalarına yönelik son görüşme formlarından elde edilen veriler

Dinleme sonrasındaki uygulamaları önceki uygulamalarınızla karşılaştırdığınızda nasıl değerlendiriyorsunuz? (çalışma yaprakları, ürün oluşturma süreci, oluşturulan ürünlerin ölçülmesine yönelik uygulamalar, değerlendirme çalışmaları vb.)

\begin{tabular}{|c|c|c|}
\hline Öğrenci & Kod & Tema \\
\hline $\begin{array}{l}\text { Ö1, Ö2, Ö3, Ö5, Ö6, Ö7,Ö9, Ö10, Ö11, Ö12, Ö13, Ö14, Ö15, Ö16, Ö17, Ö20, } \\
\text { Ö21, Ö23: Çok beğeniyorum, güzel oluyor. }\end{array}$ & Etki etme & \multirow{4}{*}{$\begin{array}{c}\text { Dinleme sonras1 } \\
\text { uygulamaları }\end{array}$} \\
\hline $\begin{array}{l}\text { Ö2, Ö4, Ö5, Ö8, Ö11, Ö17, Ö18, Ö22: Dinlediklerimize yönelik değerlendirmede } \\
\text { bulunuluyor. Sorular konuyla ilgili. }\end{array}$ & $\begin{array}{l}\text { Metne yönelik } \\
\text { olma }\end{array}$ & \\
\hline Ö3, Ö4, Ö8, Ö19: Derse daha fazla katılma isteği duydum. & Öğrenci katılımı & \\
\hline $\begin{array}{l}\text { Ö3, Ö4, Ö5, Ö6, Ö11, Ö12, Ö13, Ö14, Ö15, Ö17, Ö20, Ö21, Ö23: Çalışma yap- } \\
\text { raklar1 çok eğlenceli oluyor. }\end{array}$ & Çalışma yaprak- & \\
\hline Ö2, Ö3, Ö5, Ö7, Ö10, Ö11, Ö18, Ö22: Öz değerlendirme çok eğlenceliydi. & Öz değerlendirme & \multirow{2}{*}{$\begin{array}{l}\text { Ölçme değerlen- } \\
\text { dirme }\end{array}$} \\
\hline $\begin{array}{l}\text { Ö4, Ö10, Ö16, Ö17, Ö18, Ö19: Yaptığım ürüne neye göre puan verdiğinizi bilmek } \\
\text { çok iyi oluyor. }\end{array}$ & & \\
\hline
\end{tabular}

Tamamlayıcı ölçme değerlendirme araçlarının kullanımının dinleme becerisinin gelişiminin ölçülmesinde etkili olduğu anlaşılmıştır. Yürütülen uygulamalarda kullanılan kaba değerlendirme formu, bütüncül puanlama anahtarı, öz değerlendirme formu, kontrol listesi, gözlem formları, görüşme formları ve öğrenci günlüklerinin öğrencilerin dinleme başarısının değerlendirilmesinde rol oynadığı sonucuna ulaşılmıştır. Dinleme diğer dil becerilerine benzer şekilde değerlendirilememektedir. Konuşma becerisi değerlendirilirken konuşma, okuma becerisi değerlendirilirken okuma, yazma becerisi değerlendirilirken yazma becerisi kullanılmaktadır. Ancak dinleme becerisinin değerlendirilmesinde dinleme dışındaki becerilerin kullanımına ihtiyaç duyulmaktadır. Bu nedenle öğrencinin dinleme becerisinin gelişiminin belirlenmesinde diğer dil becerilerini kullanabilme başarısı da rol oynamaktadır. Öğrencinin süreç içerisinde değerlendirilmesinin, dinleme başarısının belirlenmesine etki edeceği düşünülmektedir. Bu nedenle süreç değerlendirmeyi temel alan tamamlayıcı ölçme değerlendirme araçlarının kullanımın dinleme becerisinin ölçümünde kullanımına yer verilmesi gerekmektedir.

\section{Tartışma ve sonuç}

Dinleme geliştirilebilir bir dil becerisidir (Aytan, 2011; Cihangir Çankaya, 2015; Çayl1, 2012; Doğan, 2007; Doğan, 2008; Epçaçan, 2013; Melanlığlu, 2012a; Tabak ve Göçer, 2014; Yıldız, 2015). Yapılan uygulamalarda, dinleme becerisinin gelişiminin desteklenebildiği (Doğan, 2007; Doğan, 2008; Kaya, 2015; İşeri ve Y1lmaz, 2008; Miller, 2003; Y1ldız, 2015) ifade edilmektedir.

Ortaokullarda dinleme becerisinin gelişimine yönelik yürütülen uygulamalara etki eden bazı unsurlar bulunmaktadır. Araştırmada bu unsurlar ortaya koyulmaktadır. Eylem süresince hazırlanan planlar 2018 Türkçe Dersi Öğretim Programına göre düzenlenmiştir. İlk eylem planında 6. sınıf düzeyinde dinleme öncesine yönelik kazanımlarda eksiklik olduğu görülmüştür. Literatürde öğretmenlerin kazanımları yeterli bulmadığına yönelik görüşlere ulaşan araştırmalar ortaya çıkan sonucu desteklemektedir (Çaylı, 2012; Durukan, 2013; Göçer ve Çaylı, 2019).

Dinleme becerisinin gelişimine yönelik derslerde materyal kullanımının öğrencilerin dinlediklerini somutlaştırmasına yardımcı olduğu görülmektedir. "Piaget, soyut işlemler döneminin bireyin 11 yaşına girmesiyle başladığını belirtilmektedir” (Senemoğlu, 1997). Araştırmada soyut işlemler dönemine yeni giren öğrenciler için materyal kullanımının ve kullanılan materyallerin çeşitlendirilmesinin önemi fark edilmektedir. Materyal kullanımının sürece etkileri öğrenci tepkilerini gösteren gözlem notlarından anlaşılmaktadır. Öğrencilerin; eylem planı 1'de kullanılan çalışma yapraklarına, eylem planı 4'ten itibaren yer verilen dinleme öncesine yönelik görsel içerikli bilgisayar sunularına, eylem planı 4 ve 5'te araştırmacı tarafından seslendirilen dinleme metnine, eylem planı 7 ve 8 'de hazırlanan dinleme metnine yönelik memnuniyetleri gözlem formlarında görülmektedir.

Dinleme öncesi yapılan hazırlık çalışmaları sürece etki etmektedir. Hazırlık çalışmalarında "temel amaç metin işleme sürecinde öğrencilerin metin aracılığıyla öğrenme etkinliklerine daha etkin katılımlarına hazır hâle gelmelerini sağlamaktır” (Göçer, 2017: 118). "Berne’ye (2004) göre dinleme öncesi etkinlikler öyle tasarlanmalıdır ki bu etkinlikler ile öğrencilerin dinlemeye karşı motivesi artmalı, ön bilgileri harekete geçebilmelidir" (Jones ve Plass, 2002; Akt. Temur, 2010: 309). "Dinleme öncesinde; öğrencinin istekli hâle getirilmesi, ilgi ve dikkatin konu üzerine çekilmesi, merak duygusunun uyandırılması, dinleme kurallarının hatırlatılması, dinleme türü hakkında 
bilgi verilmesi dinlediğini anlama başarısına etki edebilir. Bu sebeple dinleme metnine geçmeden önce öğrencilerin olabildiğince derse hazır hâle gelmesi gerekmektedir" (Göçer ve Çaylı, 2019: 473). "Öğretmenler dinleme çalışmalarından önce hazırlık yapmalı, dinleme becerisini geliştirebilecek alternatif etkinlikler tasarlamalıdır. $\mathrm{Bu}$ noktada araştırmada yer alan aktif öğrenme tekniklerine dayalı ders planlarına benzer materyallerden ya da Türkçe Öğretimi etkinlik kitaplarından yaralanmalıdır" (Aytan, 2011: 42).

Öğrencinin dikkatini ve ilgisini çekerek, metne yönelik bir ön görü oluşturmak ve merak uyandırmak dinleme sürecine katkı sağlamaktadır. Dinleme öncesi yapılan hazırlık çalışmaları, öğrencinin; zihinsel olarak farkındalık kazanmasında, bilişsel ve duyuşsal olarak yeterli hazırbulunuşluğa ulaşmasında rol oynamaktadır. "Öğrencilerin ön bilgilerini harekete geçirerek bilişsel ve duyuşsal olarak yeni öğrenmelere hazır olmaları, hedeflenen kazanımlara ulaşılması açısından büyük öneme sahiptir" (Göçer, 2017: 118). Bu nedenle, sürecin verimli ilerleyişine etki eden hazırlık uygulamalarının üzerinde dikkatle durulması önemli görülmektedir.

Araştırmada dinleme öncesi yapılan hazırlık uygulamalarında görsel ögelerin kullanımının sürece etki ettiği anlaşılmaktadır. Bu durum eylem planı 4 sonras1; Ö1, Ö3, Ö4, Ö5, Ö6, Ö7, Ö8, Ö9, Ö10, Ö12, Ö14, Ö18, Ö20'nin; eylem planı 5 sonrası Ö1, Ö2, Ö4, Ö5, Ö7, Ö8, Ö9, Ö10, Ö11, Ö13, Ö18, Ö19, Ö20, Ö21'in; eylem planı 6 sonras1 Ö3, Ö4, Ö7, Ö9, Ö10, Ö11, Ö15, Ö20'nin öğrenci günlüklerindeki ifadelerden ve eylem planı 7'de yer alan gözlem formundaki verilerden anlaşılmaktadır. Kullanılan görsel unsurların hareketli ve müzik destekli olması görsel hazırlı̆ğın niteliğine etki etmektedir. Sunu, video, canlandırma gibi uygulamalar ile öğrencinin metne hazırlanmasının, dinlediğini anlama başarına etki ettiği araştırma süresince görülmektedir. Metne hazırlık uygulamalarının derse olumlu etkileri, hazırlık uygulamalarında görsel unsurların kullanımıyla daha da artmaktadır.

Dinleme sürecinin her aşamasında görsel materyallerin kullanımı uygulamalara etki etmektedir. "CD, DVD veya video gibi sınıfta uygulanan birçok dinleme materyali seçeneği vardır" (Bello, 2018: 63). "Winn (1988: 146) dinleme eğitimi çalışmalarında görselliği kullanarak önemli adımları ve süreci gözden geçirmek, öğrencilerin bu çalı̧̧madan daha yüksek verim elde etmelerini sağlar" (Akt. Doğan 2008: 265) demektedir. "Öğrencilerin dinlediğini anlama becerilerinin geliştirilmesinde farklı materyallerden yararlanılmasının önemli olduğu kadar dinlediğini anlama yeterliklerinin belirlenmesinde de imkânlar ölçüsünde görsel-işitsel araçlardan da yararlanılmalıdır" (Göçer, 2019: 51). Dinleme metinlerinin görsel unsurlarla desteklenmesinin yanı sıra dinleme öncesi ve sonrası uygulamalarda da görsel ögelere yer verilmesinin etkileri araştırmada görülmektedir. Dinleme öncesinde öğrencilerin metne hazırlanması, dinleme sürecinin önemli aşamalarından biri olarak dikkat çekmektedir. Bu aşamada öğrencilerin metne hazırlanmasına destek olacak video, fotoğraf, sunu vb. görsel materyallerin kullanımının sağlanması gerekmektedir. Bu uygulamalar, öğrencilerin derse olan ilgisini artırmakta, metnin anlaşılmasına katkı sağlamaktadır. Bu durum eylem planı 5 sonrası incelenen öğrenci günlüklerindeki ifadelerden anlaşılmaktadır.

"Türkçe ders ve öğretmen kılavuz kitabında yer alan metin ve temalar, Türkçe dersinin temel yapı taşlarıdır" (Şahin ve Bayramoğlu; 2016: 2102). "Dinleme metinleri, öncelikle kendi içerisinde yapıca ve anlamca bütünlük taşıyan, öğrencinin yaş ve düzeyine uygun, tema ile uyumluluk gösteren metinler olmalıdır. Metinlerde söz konusu niteliklerden birinin yer almamasının, diğer öngörülerin de gerçekleşmesini geçersiz hâle getirdiği söylenebilir" (Gündoğdu, 2011: 1218). Araştırma süresince seçilen metinlerde; metnin türü, metnin uzunluğu, ilk kez karşılaş1lan sözcük sayısı ve metnin orijinalliği gibi unsurların göz önünde tutulmasının uygulamalara etki ettiği görülmektedir.

Literatürdeki araştırmalar, metin türünün metnin anlaşılmasında rol oynadığına dikkat çekmektedir. Diakidoy, Stylianou, Karefillidou ve Papageorgiou (2005: 69) metin türüne göre; genel olarak, öğrencilerin açıklayıcı metinleri anlama seviyesinin, öyküleyici metinleri anlama seviyesinden düşük olduğunu belirtmektedir. Yıldırım, Yıldız, Ateş ve Rasinski (2010: 1) beşinci sınıf düzeyinde yaptı̆̆ araştırmasında hem okumada hem de dinlemede öyküleyici metnin bilgi verici metinden daha iyi anlaşıldığını ifade etmektedir. Katrancı (2012: 59) ise araştırmasında, bilgilendirici metin testlerinde okuduğunu ve dinlediğini anlama arasındaki ilişkinin öyküleyici metinlere göre daha düşük olduğundan bahsetmektedir. Uygulamadaki metinlerin seçildiği Türkçe kitapları incelendiğinde dinleme metinlerinde daha çok hikâye türünde metinlerin yer aldığı görülmektedir. Kemiksiz (2016: 27) incelediği 36 metnin içinde en çok yer verilen metin türünün hikâye olduğunu belirtmiştir. Eylem planı 2 ve 3 'ten elde edilen verilerle, öğrencilerin olay yazılarını düşünce yazılarından daha çok dinlemeye istekli oldukları sonucuna ulaşılmaktadır. İlerleyen eylem planlarında da bu durum görülmektedir. Eylem planı 8'de Ö1, Ö2, Ö4, Ö7, Ö8, Ö11, Ö12, Ö14, Ö20, Ö21 ve Ö22'nin metin türüne yönelik öğrenci günlüklerindeki ifadeleri ve araştırmacı günlüğ̈̈ndeki ifadeler düşünce yazısı türündeki metinlerin dinleme sürecine etki ettiğini göstermektedir. "Ö15: Öğretmenim türü makale olmasaydı keşke. Ö22: Ben anlamam ya bu metni. Ö20: Keşke gene masal dinleseydik anlayamam ki bu metni” şeklinde eylem planı 3'te yer alan öğrenci ifadeleri düşünce yazılarında öğrencilerin dinlediklerini anlayamayacaklarına yönelik bir ön yargı içerisinde olduğuna dikkat çekmektedir. Araştırma sonucunda dinleme 
metinlerinin türünün dinleme sürecine etki ettiği anlaşılmaktadır. Bu sebeple; ilk ve ortaokul düzeyinde dinleme zevki kazandıracak olay türünde metinlerin kullanımına özen gösterilmesinin, sınıf seviyesi ilerledikçe düşünce yazılarına yer verilmesinin dinleme becerisinin gelişimine etki edeceği düşünülmektedir.

Dinleme metinlerinin uzunluğu, öğrencilerin dinlediklerini anlamasına ve dinleme sürecine etki etmektedir. Bu durum, eylem planı 2'de metnin uzun olmasına dikkat çeken Ö1, Ö9, Ö10, Ö12, Ö13, Ö18'in öğrenci günlüklerinden anlaşılmaktadır. "Öğrencilerin dil ve zihinsel becerilerinin geliştirilmesinde metin türü kadar metin uzunluğunun önemli bir yeri vardır" (Güneş, 2013: 9). Metinlerde yer alan sözcüklerle ilgili olan araştırmasında "Fayard (2005) 6-8. sınıfların 1.500 kelimelik metinleri rahatlıkla anladıklarını saptamıştır” (Akt. Güneş, 2013: 9). Araştırmada; dinleme metinlerinde metnin uzunluğunun dinlediğini anlama başarısına etki ettiği görülmektedir. Metnin süresi uzadıkça öğrencinin dikkati dağılmakta, metne yönelik önemli ayrıntıları kaçırabilmektedir. Bu sebeple özellikle dinleme metinlerinde metnin uzunluğuna dikkat edilmesinin önemli olduğu düşünülmektedir.

Dinleme metninde yer alan anlamı ile ilk kez karşılaşılan sözcüklerin sayısı, öğrencilerin dinlediklerini anlamasına ve dinleme sürecine etki etmektedir. Yürütülen ilk eylem planı sonrası Ö2, Ö4, Ö7, Ö13, Ö14, Ö15, Ö17, Ö18, Ö20, Ö22'nin öğrenci günlükleri ve araştırmacı günlüğünden elde edilen veriler dinleme metinlerinde ilk kez karşılaşılan sözcük sayısının önemini ortaya koymaktadır. Ayrıca ilk kez karşılaşılan sözcükler dinlediğini anlama başarısına etki etmekte, öğrenciler ilk kez karşılaşılan sözcüklerin çok olduğu paragrafta yer alan sorulara cevap vermekte zorlanmaktadır. Bu sebeple Türkçe derslerinin farklı saatlerinde sözcük öğrenimini önceleyen uygulamaların üzerinde durulmasının, dinleme becerisinin gelişiminde rol oynayacağı düşünülmektedir.

Öğrencilerin dinleme metninin konusunu önceden biliyor olması dinlediğini anlama başarısını etkilemektedir. Eylem planı 1'de öğrencilerin dinleme metnini bilmediği ancak metnin konusunu bildikleri anlaşılmaktadır. Metnin konusuna yönelik bilginin, dinleme sürecine etki ettiği görülmektedir. Araştırmada önceden bilinen metin ya da içeriğin, dinlediğini anlama başarısı değerlendirilirken doğru sonuçlar alınamamasına sebep olduğu görülmektedir. Bu sebeple dinleme metinlerinin orijinal olması gerekmektedir. Ayrıca öğrencilerin daha önce duydukları dinleme metinlerini dinlerken dikkat ve istekliliğini kaybedebileceği düşünülmektedir.

Araştırmada yürütülen eylem plan 2'de, metni dinleme sayısının dinlediğini anlama başarısına etki ettiği ortaya çıkmaktadır. Dinleme sayısının belirlenmesinde; dinleme metninin uzunluğunun, metnin içeriğinin, metin türünün, öğrenci hazırbulunuşluk düzeyinin dikkate alınması sürece etki etmektedir.

Dinleme metinleri; ses dosyası, görsel destekli ses dosyası, video, film, misafir seslendirici vb. kullanılarak sunulabilmektedir. Dinleme metinlerinin sunuluş şeklinde, metnin niteliğinin rol oynadığı anlaşılmıştır. Araştırmada metnin sunuluş şeklinin belirlenmesinde; metin türünün, içeriğinin, uzunluğunun vb. unsurların önemi ortaya çıkmaktadır. Ayrıca metnin niteliğine göre düzenlenen ses dosyası, görsel destekli ses dosyası, video ya da misafir seslendirici gibi farklı kullanımlar derse olan ilgiyi etkilemektedir.

Dinleme metinlerine erişim ses dosyası veya görsel içerikli ses dosyalarıyla mümkündür. Dinleme metinlerine EBA ya da farklı platformlar üzerinden erişim mümkündür. Ancak Çaylı (2019: 440) 5-8. sınıfta yer alan 32 dinleme metninin 12 tanesinin EBA üzerinde yer aldığını belirtmektedir. Dinleme metinlerinin sadece bir kısmı "yansıt-oku" şeklinde internet üzerinde metin olarak bulunabilmektedir. Hazırlanan ses dosyalarının ulaşılabilir olmasının yanı sıra, nitelikli olması da önemlidir. Eylem planı 3'te hazır ses dosyası kullanılmıştır. Uygulama sonrası Ö2, Ö6, Ö9, Ö10, Ö13, Ö17, Ö21, Ö23'ün günlüklerinden ve eylem planı 4'teki gözlem notlarından elde edilen veriler okuyucu hızının dinleme sürecine etki ettiğini göstermektedir. Elde edilen sonuç sonrası seslendirmeler araştırmacı tarafindan yapılarak görsellerle desteklenmiştir. Her öğretmenin dinleme metinini dijital ortamda seslendirme ve görsellerle destekleme imkânı ve yeterliliği olmadığı için bu konuda yayınevlerine ve Millî Eğitim Bakanlığına önemli görevler düşmektedir. Ayrıca dinleme metinlerinde; okuyucu hızı, fon müziğinin metin ile uyumu ve şiddeti, vurgu ve tonlama gibi unsurlara dikkat edilerek seslendirmelerde bulunulmasının dinleme sürecine etki edeceği düşünülmektedir.

"Dinleme stillerinin bilinmesi ve öğrencilere olumlu dinleme stillerini uygulama firsatı verilmesi dinleme eğitimine katkı sağlayabilir" (Epçaçan, 2013: 344). Araştırma sonucunda farklı dinleme stillerinin kullanılmasının dinlediklerini anlama başarısına etki ettiği görülmektedir. Bireysel farklılıklar farklı dinleme stillerinin kullanımını gerekli kılmaktadır. Her öğrenci farklı özelliklere sahiptir. Bu sebeple bir eğitim öğretim dönemi boyunca öğrencinin farklı dinleme stillerini uygulamasına imkân verilmesinin yerinde olacağı düşünülmektedir. Öğrencilerin; metnin sunuluş şekline (işitsel, görsel/işitsel, misafir seslendirici gibi), içeriğine, niteliğine, türüne göre kendine uygun dinleme stilini seçebilme erişkinliğini kazanabilmesi için süreç içerisinde farklı dinleme stillerini aktif olarak uygulaması gerekmektedir. Öğrencilerin dinleme stilleri hakkında bilgi ve uygulama eksiklikleri dikkate alınarak, eksik ve yanlış bilgilerin süreç içerisinde tamamlanarak düzeltilmesi önemli görülmektedir. "Wortington Copyright $(\mathcal{O} 2022$ by IJSSER 
(2008) anlama ihtiyacıyla dinleme eylemine giren kişi amaç, süre, ortam vb. etkenlere bağlı olarak farklı dinleme davranışları sergiler. İlgili alanyazında bireyin sergileyebileceği birçok dinleme türü tanımlanmaktadır. Her dinleme türü aynı zamanda birer dinleme alışkanlığı ya da stilidir. İnsan, farklı dinleme türlerini farklı ortamlarda sergileyebilir ya da farklı dinleme alışkanlıkları kazanarak dinleme alışkanlık ya da stilini değiştirebilir. Bu bağlamda herkesin farklı dinleme alışkanlığına ya da stiline sahip olduğu ortaya çıkmaktadır. Bireylerin sahip olduğu farklı dinleme stilleri vardır. Birey dinleme etkinliklerinde baskın olan stilini kullanır" (Akt. Maden ve Durukan, 2011: 104). Bireyin kendi dinleme stilini, dinlediği ortama ve şartlara uygun şekilde seçebilme becerisini edinmesinde okullarda yürütülen dinleme becerisinin gelişimine yönelik derslerin katkısı büyüktür. Bu sebeple dinleme becerisine yönelik uygulamalarda öğretmenlerinin farklı dinleme stillerinin kullanımını öğrencilere fark ettirmesi gerekmektedir. "Türkçe öğretmeni adaylarının \%48,4'ünün pasif dinleyici, \%32,7'sinin katılımcı dinleyici, \%16,4'ünün tarafsız dinleyici ve \%4'ünün aktif dinleyici oldukları" (Maden ve Durukan, 2011: 109) ifade edilmektedir. Öğretmenlerin farklı dinleme stillerinin kullanımına yönelik tutumları derslerdeki uygulamalarına etki edebilir. Aktif olarak dinleme sürecine dâhil olmaya alışkın öğretmenlerin, öğrencilerini de sürece dâhil etmeye istekli olacağı düşünülmektedir. Ortaokul Türkçe derslerinde dinleme stilinin belirlenmesinde metnin niteliğine, metnin sınıfa sunuş şekline, öğrenci hazırbulunuşluk düzeyine, sınıf içi ortama vb. dikkat edilmesi gerekir. Dinleme stilinin seçiminde; metnin türü ve uzunluğu, ilk kez karşılaşılan sözcük sayısı, metnin konusu gibi metinden kaynaklı unsurların göz önünde tutulması süreci etkilemektedir. Öğrencilerin farklı dinleme stillerini etkili olarak kullanabilme yeterliliğine erişmesinin günlük hayatta önemli ve büyük bir yer tutan dinleme ortamlarında öğrenciye katkı sağlayacağı düşünülmektedir.

Dinleyici faktörünün dinleme sürecine etkileri araştırma süresince fark edilmektedir. "Dinlemenin canlı yapısı, dinleyenin daha dikkatli, dinleme yaşantıları bakımından daha hazır olmasını gerektirmektedir" (Çifçi, 2001: 170). Bu dikkatlilik hâlinin öğrencinin derse olan ilgisinin artırılmasıyla mümkün olduğu düşünülmekte ve süreç içerisinde aktif öğrenci katılımına yer verilmesi gerekli görülmektedir. Eylem plan1 9'da Ö1, Ö2, Ö3, Ö4, Ö5, Ö7, Ö8, Ö9, Ö10, Ö11, Ö15, Ö17, Ö19, Ö21'in öğrenci günlüklerinde yer alan ifadeler, metnin anlaşılmasında öğrencinin sürece aktif katılımının etkisini ortaya koymaktadır.

Eğitimin vazgeçilmez bir parçası olan ölçme değerlendirme uygulamaları, hedef ve kazanımlara ulaşma durumu hakkında uygulayıcılara yol göstericidir. Bu sebeple öğretmenlerin dinleme sürecinin her aşamasında ölçme değerlendirme uygulamalarına yer vermesi gerekmektedir. Ancak dinleme becerisini değerlendirmeye yeteri kadar önem verilmediği (Göçer, 2019: 50), değerlendirmede eksiklikler olduğu (Epçaçan, 2013: 345; Göçer, 2019: 50) ve diğer becerilere göre ölçme değerlendirme çalışmalarında zorluklarla karşılaşıldığı (Melanlığlu ve Karakuş Tayşi, 2013: 31) ifade edilmektedir. Dinleme becerisi diğer dil becerileri gibi ölçülememektedir. Konuşma, yazma ve okuma başarısının değerlendirilmesi aynı beceri kullanılarak yapılabilmektedir. Ancak dinlediğini anlama başarısı ve dinleme süreci hakkında değerlendirme yapılabilmesi için konuşma ve/veya yazma becerisine ihtiyaç duyulmaktadır. Öğrencinin dinleme başarısındaki yeterliliğini gösterebilmesi, diğer dil becerilerini kullanabilme yeterliliğine bağlıdır. Bu sebeple dinleme becerisinin gelişim durumunun değerlendirilmesi için süreç değerlendirmesi (Epçaçan, 2013: 344; Melanlıŏglu 2012a: 1585; Melanlığlu ve Karakuş Tayşi, 2013: 31) ve hem süreç hem sonuç değerlendirmesi (Göçer, 2019: 52) kullanımının uygun olacağı düşünülmektedir. "Eğitim sürecinin hedeflenen doğrultuda planlanıp sürdürülmesi ve amaca hizmet edecek şekilde tamamlanabilmesi için değerlendirmeye önem verilmesi ve gereken zamanın ayrılması zorunludur. Bu zorunluluğun yerine getirilmesinde süreçte uygulanabilecek farklı değerlendirme yöntem ve araçların işe koşulması gerekir”' (Göçer, 2019: 52).

Öğrencilere süreç içerisinde dağıtılan çalışma yaprakları sürecin sonuçlarını almakta öğretmene rehber olmaktadır. Hazırlanan çalışma yapraklarının, sürece uygun şekilde öğrencilere verilmesi; öğrencilerin yeri geldikçe, metne yönelik sorularla karşılaşması sürecin düzenli ve kontrol edilir şekilde ilerlemesini sağlamaktadır. Temur (2010: 314-315) yaptığı araştırmada dinleme metinlerine yönelik olarak sorulan soruların; dinleme öncesinde verilmesinin seçici dinlemeye, dinleme sonrasında verilmesinin de metnin tümüne odaklanılmasına sebep olduğunu ifade eden bulgulara dikkat çekmektedir. Dinleme süreci göz önüne alınarak hazırlanan çalışma yapraklarında; dinleme öncesinde yer alan soruların metnin orijinalliğine zarar vermemesi, merak ve ilgi uyandırabilmesi ve metne yönelik hazırbulunuşluğu destekleyici nitelikte olması gerekmektedir. Dinleme sırası ve sonrasında cevaplanacak soruların ise metne yönelik olmasına özen gösterilmesi önemlidir. Metinle ilişkisi olmayan soruların cevaplanması, dinlediğini anlama başarısının ortaya koymamaktadır. Dinleme sırasında kullanılan çalışma yaprakları; hem sürecin aşamalarında hem de sonucun değerlendirilmesinde etkili olmaktadır.

Dinleme süreci içerisinde geleneksel ölçme değerlendirme araçlarının yanı sıra tamamlayıcı ölçme değerlendirme araçlarının da kullanımının sağlanması dinleme başarısının ölçümüne yardımcı olmaktadır. "Dinleme bece- 
risi, kapsamı bakımından bilişsel, duyuşsal ve devinişsel alanlara dâhil olacağından bu becerinin ölçülüp değerlendirilmesinde alternatif ya da tamamlayıcı olarak nitelendirilen birden çok değerlendirme aracının kullanılması da zorunluluk hâlini almaktadır" (Göçer, 2018: 215). Araştırmada eylem planlarında yer verilen; kaba değerlendirme formu, öz değerlendirme formu, bütüncül puanlama anahtarı, kontrol listeleri, gözlem formları, görüşme formları ve öğrenci günlüklerinin kullanımı dinleme becerisinin gelişim durumunun belirlenmesinde yol gösterici olmaktadır. Ayrıca öğrencilerin öz değerlendirme formlarıyla ölçme değerlendirme sürecine dâhil olmasının, öğrenciye etki ettiği Tablo 35'te gösterilen son görüşme formunun dördüncü sorusuna verilen Ö2, Ö3, Ö5, Ö7, Ö10, Ö11, Ö18 ve Ö22'nin ifadelerinden anlaşılmaktadır. Bununla birlikte süreç içerisinde kullanılan ölçme değerlendirme araçlarındaki ölçütlerin öğrenciler tarafından değerlendirme öncesi bilinmesi, öğrencinin değerlendirme uygulamalarına farklı bir bakış açısı kazanmasını sağlamaktadır. Tablo 35'te yer alan Ö4, Ö10, Ö16, Ö17, Ö18 ve Ö19'un ifadeleri bu durumu ortaya koymaktadır. Dinleme sürecinde geleneksel ölçme değerlendirme araçlarının yanı sıra; öz değerlendirme, akran değerlendirme, kaba değerlendirme, bütüncül puanlama anahtarı, rubrik, gözlem formu, görüşme formu gibi tamamlayıcı ölçme değerlendirme araçlarının kullanımının sürece etki edeceği düşünülmektedir. Ayrıca dinleme becerisinin değerlendirilmesinde "süreç değerlendirme uygulamalarının yanında -tıpkı okuduğunu anlama becerisinin değerlendirilmesinde olduğu gibi- yazılı sınavlar" (Göçer, 2019: 57) yapılması da önerilmektedir.

Dinleme becerisinin belirlenmesine yönelik uygulamalarda kullanılan ölçme değerlendirme araçlarının yanı sıra uygulamalarda, öğrencilerin öğrendiklerini içselleştirebilmesi ve içselleştirdiklerini gösterebilmesine olanak sağlayacak ortamların oluşturulması önemli görülmektedir. Eylem planı 6'da öğrencilerin ürün oluşturmak kadar, oluşturdukları ürünleri sınıfta sunmaya istekli oldukları gözlem formundan anlaşılmaktadır. Ayrıca eylem planı 5 ve 7'de yer alan öğrenci günlüklerindeki ifadeler ile eylem planı 7 ve 8'de yer alan gözlem notları ürün oluşturma sürecinin öğrenciye etki ettiği göstermektedir. Sürecin içselleştirilerek tamamlanması, yapılandırmacı yaklaşımın ruhuna uygun olmaktadır. Yapılandırmacı yaklaşım anlayışla yürütülen derslerde; ilgi kurma ve ilişkilendirmenin yapılması, öğrencilerin eski öğrenmeleri ile yeni öğrenmelerini kaynaştırabileceği ortamlar hazırlanması önemlidir. Bu sebeple, ders sonunda öğrencilerin öğrendiklerini ortaya koyabilmesine imkân veren uygulamalara araştırmada yer verilmektedir. Öğrencilerin içselleştirdiği bilgiyi ortaya koyabilecek bir ürün oluşturabilmesi, dinlediği anlama başarısının göstergesi olarak görülmektedir. Oluşturulacak ürünlerin nitelikli olabilmesi ve sınıf içerisinde sunulabilmesi için ürün oluşturma uygulamalarına ayrılacak süreye dikkat edilmesi gerekir.

\section{5. Öneriler}

- Türkçe öğretim programı 5-8. sınıf seviyesinde dinleme öncesine yönelik kazanımlardaki eksiklikler tamamlanmalıdır.

- Türkçe derslerinde kullanılacak dinleme metinlerinde-anlamı ile ilk kez karşılaşılacak sözcük sayısına, metin türüne, metnin güncelliğine, içeriğine, uzunluğuna ve konusuna dikkat edilmelidir.

- Dinleme metini ses dosyalarında fon müziği, okuma hızı gibi unsurlara dikkat edilerek seslendirmeler yapılmalidır.

- Görsel destekli ses dosyaları ve videolarda nitelikli görsel unsurlara yer verilmeli, ilgili kurum ve kuruluşların desteği ile her sınıf seviyesindeki sayılı dinleme metinine yönelik görsel destekli ses dosyaları veya video hazırlanmalıdır.

- Dinleme öncesi metne hazırlık çalı̧̧malarına dikkat edilmeli, öğretmenler gerekli görürse bir ders saati metne hazırlık uygulamalarında bulunmalıdır. Derse hazırlık uygulamalarında görsel destekli materyal kullanımına özen gösterilmelidir.

- Dinleme metinlerinin dinlenme sayısı metnin niteliğine göre belirlenmelidir. Her metin için aynı dinleme sayısı kullanılmamalıdır.

- Dinleme becerisine yönelik müstakil bir internet platformu kurulmalıdır. Kurulan ağ $\breve{g}^{2}$ aktif olarak kullanılmalıdır.

- Dinleme metninin niteliğine göre dinleme metninin sunuluş şekli (ses dosyası, görsel destekli ses dosyası, video, misafir seslendirici vb.) belirlenmelidir. Dinleme metninin niteliğine ve sunuluş şekline göre dinleme stili belirlenmeli, dinleme stilleri farklılaştırılarak derslerde kullanılmalıdır.

${ }^{2}$ Adres önerisi 1: www. dibega.gov.tr. (dinleme becerisini geliştirme ağı)

Adres önerisi 2: www. diba.gov.tr (dinleme becerisi ağı) 
- Öğrencilerin kolay anlayacağı, zevk aldığı olay türünde metinlerin kullanımı öncelenmeli; ilerleyen sınıf seviyelerinde kademeli olarak düşünce yazısı türünde metinlere yer verilmelidir.

- Dinleme metinlerine yönelik sorular ders kitaplarından çıarılmalı, öğrencilerin soruları önceden görmesi engellenmelidir. Bu amaçla çalışma yaprakları hazırlanmalı, hazırlanan çalışma yaprakları dinleme öncesi, sırası ve sonrasına göre aşamalı olarak öğrencilere dağıtılmalıdır.

- Ürün oluşturma uygulamalarının sürece dâhil edilmesine özen gösterilmelidir. Öğrencilere verilecek süre ürünün hazırlanmasına ve sunumuna yetecek şekilde planlanmalıdır.

- Dinleme becerisinin gelişim durumunun belirlenmesinde süreç ve sonuç değerlendirmesi yapılmalıdır. Öğrencilerin dinleme becerilerinin gelişim durumunun belirlenmesinde geleneksel ölçme değerlendirme araçlarının yanı sıra tamamlayıcı ölçme değerlendirme araçlarından etkili şekilde faydalanılmalıdır.

\section{Yazarların katkı oranı beyanı}

Yazarlar makalenin veri toplama, veri analizi, raporlaştırma ve diğer aşamalarından eşit düzeyde sorumlu olduğunu beyan eder.

\section{Çıkar çatışmast}

Bu çalışmada yazar tarafindan herhangi bir çıkar çatışması belirtilmemiştir.

\section{Etik kurul onayı}

Bu araştırma Kayseri Valiliği, İl Millî Eğitim Müdürlüğü tarafindan 11.01.2018 tarihinde, 94025929-609,02E.852280 say1lı izin belgesi alınarak yürütülmüştür. Tüm sorumluluk yazarlara aittir.

\section{Kaynakça}

Aksoy, N. (2003). Eylem araştırması: Eğitimsel uygulamaları iyileştirme ve değiştirmede kullanılacak bir yöntem. Kuram ve Uygulamada Ĕ̈itim Yönetimi, 36, 474-489.

Akyol, H. (2010). Yeni programa uygun Türkçe öğretim yöntemleri (3. bask1). Ankara: Pegem Akademi.

Aytan, T. (2011). Aktif öğrenme tekniklerinin dinleme becerisi üzerindeki etkileri. ODÜ Sosyal Bilimler Enstitüsü Sosyal Bilimler Araştırmaları Dergisi, 2(4), 23-43.

Baumfield, V., Hall, E. \& Wall, K. (2013). Action research in education (2nd ed.). London: Sage Publications.

Bello, A. A. (2018). Curriculum implementation: Strategies for mounting listening skills among junior secondary school students. Journal of Pedagogical Research, 2(1), 63-77.

Berg, B. L. ve Lune, H. (2015). Sosyal bilimlerde nitel araştırma yöntemleri (Çev. ed.: H. Aydın). Konya: Eğitim Kitabevi.

Cihangir Çankaya, Z. (2015). Kişilerarası iletişimde dinleme becerisi (3. baskı). Ankara: Nobel Akademi Yayıncılık.

Çaylı, C. (2012). İkinci kademe Türkçe dersi öğretmen kılavuz kitaplarındaki müstakil dinleme metinlerine yönelik öğretmen uygulamalarının değerlendirilmesi. Yayımlanmamış yüksek lisans tezi. Erciyes Üniversitesi, Kayseri.

Çaylı, C. (2019). Ortaokul Türkçe öğretmenlerinin dinleme becerisinin gelişimine yönelik olarak EBA (eğitim bilişim ağı) paylaşımları üzerine görüşleri. II. Uluslararası Sosyal Bilimler Kongresi Tam Metin Kitabı içinde (ss. 430-441). Nevşehir.

Çifçi, M. (2001). Dinleme eğitimi ve dinlemeyi etkileyen faktörler. Afyon Kocatepe Üniversitesi Sosyal Bilimler Dergisi, 2(2), $165-177$.

Diakidoy, I. A., N., Stylianou, P., Karefillidou, C. \& Papageorgıu, P. (2005) The relationship between listening and reading comprehension of different types of text at increasing grade levels. Reading Pyschology, 26(1), 55-80.

Doğan, Y. (2007). İlköğretim ikinci kademede dil becerisi olarak dinlemeyi geliştirme çalışmaları. Yayımlanmamış doktora tezi, Gazi Üniversitesi, Ankara.

Doğan, Y. (2008). İlköğretim yedinci sınıf öğrencilerinin dinleme becerisini geliştirmede etkinlik temelli çalışmaların etkililiği. Türk Ĕ̈itim Bilimleri Dergisi, 6(2), 261-268.

Doğan, Y. (2013). Dinleme eğitimi: kuram, uygulama, ölçme ve değerlendirme. A. Güzel ve H. Karatay (Editörler), Türkçe ögretimi el kitabı içinde (ss. 151-175). Ankara: Pegem Akademi.

Durukan, E. (2013). Öğretmen görüşleri açısından Türkçe dersi öğretim programı kazanımları. Karadeniz Sosyal Bilimler Dergisi, 5(8).

Emiroğlu S. ve Pınar, F. N. (2013). Dinleme becerisinin diğer beceri alanları ile ilişkisi. Turkish Studies, 8(4),769-782. 
Epçaçan, C. (2013). Temel bir dil becerisi olarak dinleme ve dinleme eğitimi. Adlyaman Üniversitesi Sosyal Bilimler Enstitüsü Dergisi Türkçenin Eğitimi Öğretimi Özel Sayısı, 6(11), 331-352.

Gilman, R. A. \& Moody, R. L. (1984). What practitioners say about listening. Foreign Language Annals, 17(4), 331-334.

Göçer, A ve Çaylı, C. (2019). Ortaokul Türkçe derslerinde dinleme becerisinin gelişimine yönelik öğretmen uygulamaları. Trakya Eğitim Dergisi, 9(3), 456-476

Göçer, A. (2007). Bir öğrenme alanı olarak anlama eğitimi ve Türkçe öğretimindeki yeri. Erciyes Üniversitesi Sosyal Bilimler Enstitüsü Dergisi, 23, 17-39.

Göçer, A. (2017). Öğrenci merkezli-etkileşimli- metin işleme ve çözümleme süreçli Türkçe özel öğretim yöntemleri (geliştirilmiş 2. bask1). Ankara: Pegem Akademi.

Göçer, A. (2018). Türkçe eğitiminde ölçme ve değerlendirme (2. bask1). Ankara: Pegem Akademi Yayınları.

Göçer, A. (2019). Öğrencilerin dinlediğini anlama yeterliklerinin yazılı sınavlarla değerlendirilebilirliği üzerine. Gümüşhane Üniversitesi Sosyal Bilimler Enstitüsü Elektronik Dergisi, 10(1), 50-59.

Greenwood, D. J. \& Levin, M. (2007). Introduction to action research, social research for social change (2nd ed.). Thousand Oaks, California: Sage Publications.

Gündoğdu, A. E. (2011). İlköğretim sekizinci sınıf dinleme metinlerinin çeşitli değişkenler açısından incelenmesi. Turkish Studies, 6(1), 1217-1227.

Güneş, F. (2013). Türkçe öğretiminde metin seçimi. Ana Dili Eğitimi Dergisi, 1(1), 1-12.

İşeri, K. ve Yılmaz, İ. (2008). Dinleme edimine ilişkin etkinliklerin değerlendirilmesi. Dil Dergisi, 139, 7-24.

Jalongo, M. R. (1995). Promoting active listening in the clossroom. Childhood Education, 72(1), 13-18.

Johnson, A. P. (2015). Eylem araştırması el kitabı (2. baskı). Ankara: Anı Yayıncılık.

Kardaş, M. N., Çetinkaya, V. ve Kaya, M. (2018). 2005-2017 yılları arasında dinleme eğitimi üzerine yapılmış akademik çalışmaların eğilimleri üzerine bir araştırma. Kuram ve Uygulamada Sosyal Bilimler Dergisi, 2(1), 21-32.

Katrancı, M. (2012). Üstbilişs stratejileri öğretiminin dinlediğini anlama becerisine ve dinlemeye yönelik tutuma etkisi. Yayımlanmamış doktora tezi, Hacettepe Üniversitesi, Ankara.

Kaya, E. (2015). Ortaokul (5 - 8) Türkçe dersi dinleme eğitimi etkinliklerinin öğretmen, ögrenci ve veli görüşleri açısından incelenmesi: Durum çalışması. Yayımlanmamış yüksek lisans tezi, Atatürk Üniversitesi, Erzurum.

Kemiksiz, Ö. (2016). Türkçe derslerindeki dinleme metinlerinde dinleme yöntem/tekniği-metin türü ilişkisi. Ana Dili Eğitimi Dergisi, 4(1), 15-30.

Kemiksiz, Ö. (2017). Dinleme becerisi üzerine yazılan makalelerin değerlendirilmesi. International Journal of Languages' Education and Teaching, 5(1), 511-531

Maden, S. ve Durukan, E. (2011). Türkçe öğretmeni adaylarının dinleme stillerinin çeşitli değişkenler açısından değerlendirilmesi. Mehmet Akif Ersoy Üniversitesi Sosyal Bilimler Enstitüsü Dergisi, 3(4), 101-112.

McAteer, M. (2013). Action research in education. London: Sage Publications.

McNiff, J. \& Whitehead, J. (2011). All you need to know about action research (2nd ed.). London: Sage Publications.

Melanlığlu, D. ve Karakuş Tayşi, E. (2013). Türkçe öğretim programındaki dinleme kazanımlarının ölçme değerlendirme yöntemleri bakımından sınıflandırılması. Dil ve Edebiyat Ĕ̈itimi Dergisi, 2(6), 23-32.

Melanlığlu, D. (2012a). Dinleme becerisine yönelik ölçme değerlendirme çalışmalarında üstbiliş stratejilerinin kullanımı. Turkish Studies, 7(1), 1583-1595.

Melanlığlu, D. (2012b). Dinleme becerisinin geliştirilmesinde ailenin rolü. Sosyal Politika Çalışmaları, 7(29), 65-77.

Miller, L. (2003). Developing listening skills with authentic materials. http://dl.ueb.edu.vn/bitstream/1247/9968/1/Developing\%20Listening\%20Skills\%20with\%20Authentic\%20Materials\%281\%29.pdf. Erişim Tarihi: 14.10.2017

O'Brien, R. (2001). An Overview of the methodological approach of action research, http://www.web.ca/ robrien/papers/arfinal.html. Erişim Tarihi: 19.11.2017.

Osada, N. (2004). Listening comprehension research: A brief review of the past thirty years, Dialogue, 3, 53-66.

Özbay, M. (2006). Türkçe özel ögrretim yöntemleri II. Ankara: Öncü Kitap.

Schmuck, R. A. (2009). Practical action research (2nd ed.). Thousand Oaks, California: Corwin Press.

Senemoğlu, N. (1997). Gelişim öğrenme ve öğretim kuramdan uygulamaya. Ankara: Ertem Yayıncılık. 
Stringer, E. T. (2014). Action research (4th ed.). London: Sage Publications.

Şahin, D. ve Bayramoğlu, C. D. (2016). 2015 Türkçe öğretim programının metin tür ve tema seçimi bakımından değerlendirilmesi. Turkish Studies, 11(3), 2095-2130.

Tabak G. ve Göçer A. (2014). Dinleme becerisine yönelik alternatif ölçme ve değerlendirme araçları. Bartın Üniversitesi Eğitim Fakültesi Dergisi, 3(2), 250-272.

Temur, T. (2010). Dinleme metinlerinden önce ve sonra sorulan soruların üniversite öğrencilerinin dinlediğini anlama beceri düzeyine etkisi. Selçuk Üniversitesi Ahmet Keleşoğlu Eğitim Fakültesi Dergisi, 29, 303-319.

Townsend, A. (2013). Action research: The challenges of understanding and changing practice. England: Open University Press.

Tüzel, S. (2012). İlköğretim ikinci kademe Türkçe derslerinde medya okuryazarlı̆̆ı eğitimi: Bir eylem araştırması. Yayınlanmamış doktora tezi, Çanakkale Onsekiz Mart Üniversitesi, Çanakkale.

Xiao-yun, J. \& Gui-rong, F. (2011). Strategies to overcome listening obstacles and improve the listening abilities. US-China Foreign Language, 9(5), 315-323.

Yıldırım, A. ve Şimşek, H. (2008). Sosyal bilimlerde nitel araştırma yöntemleri (Genişletilmiş 9. baskı). Ankara: Seçkin Yayincilik.

Yıldırım, K., Yıldız, M., Ateş, S. ve Rasinski, T. (2010). İlköğretim beşinci sınıf Türk öğrencilerin metin türlerine göre okuduğunu ve dinlediğini anlama düzeyleri. Kuram ve Uygulamada Eğitim Bilimleri, 10(3), 1-37.

Yıldız, N. (2015). Dinleme stratejileri öğretiminin beșinci sınıf öğrencilerinin dinlediğini anlama becerilerine etkisi. Yayımlanmamış doktora tezi, Çanakkale Onsekiz Mart Üniversitesi, Çanakkale.

Yıldız, N., Okur, A., Arı, G. ve Yılmaz, Y. (2010). Yeni Öğretim Programına Göre Kuramdan Uygulamaya Türkçe Öğretimi (3. baskı). C. Yildız (Ed.). Ankara: Pegem Akademi. 


\section{Extended Abstract}

\section{Introduction}

"Listening plays an important role in people's lives. One of the four main areas of communication skills and language (listening, speaking, reading and writing), listening is the most basic (Gilakjani \& Ahmadi, 2011: 783). Listening skill is the most basic and first language skill for humans (Doğan, 2008: 269; İşeri \& Y1lmaz, 2008: 12; Y1ldiz, 2015: 20).

It took time to recognize the listening skill in educational settings and to support its development. "While the other three language skills (reading, writing, and speaking) attract direct attention, teachers expect students to improve their listening skills themselves, without assistance" Mendelsohn,1984; Oxford, 1993; as cited in Osada, 2004: 54).

The statement of Bello's (2018) "learning lesson methodology has been discussed and analyzed a bit, and there was a tendency for teachers that listening is an ordinary activity in life" (p. 63) shows his perspective on listening skill. Also, Bello (2018) "there is plenty of evidence that listening lacks teachers' attention. Although there was a lot of learning in the classroom, listening skill was always either passed quickly or not adequately addressed" (p. 63). These statements draw attention to the fact that the listening skill is included in the lessons.

Miller (2003) stated that there was a certain amount of work on reading, writing and speaking; however, he states that the interest on listening is lacking. Miller (2003) notes that although listening skill is described as neglected, it has recently gained more attention. In our country, it is seen that studies on listening skill are increasing. Kardaş et al. (2018: 21) in their research; It states that there has been a continuous increase in the number of researches on listening skills between 2005 and 2015, but there has been a decrease in the last two years compared to other years. In addition, Kemiksiz (2017) obtained research results that "the number of articles written on listening skills has increased significantly in recent years, and the articles are generally original and have one or two authors" (p. 511).

\section{Method}

The research was conducted with action research design within the framework of qualitative research approach. "Action research is seen as a method that is actively used by both academics and teachers who take on the role of researcher in the process, and which is used to systematically and scientifically obtain information and develop practices in various fields of education" (Kuzu, 2009: 427). "Action research is a special research method that can be used by many education staff, especially teachers, for reasons such as focusing on the solution of problems encountered in daily life, being able to be applied on small groups, and the person who has the problem to be a researcher" (Beyhan, 2013: 66). Action research is "a method that can help teachers, administrators and other school staff, who are the practitioners of education, understand their work better, affect the desired improvement and change in education and training, and solve the problems they encounter in practice using systematic ways" (Aksoy, 2003: 474). For this reason, an action research approach, which is thought to be in accordance with the spirit of the problem addressed in our research, has been adopted. Also; The fact that the researcher works as a teacher and the action research enables the researcher to participate actively in the process has been effective in the method selection.

The study group of the research consists of 23 students studying in the 6th grade of a secondary school in Kayseri. The sample included in the research was chosen for the purpose. "Purposeful sampling allows for indepth study of situations that are thought to have rich information. In this sense, purposeful sampling methods are useful in discovering and explaining facts and events in many cases" (Patton, 1987; as cited in Yıldırım \& Şimşek, 2008: 107).

The data in the research; It has been obtained from student documents, observation forms, semi-structured interview forms, researcher diary and student diaries. Data collection tools used in collecting data during the research process were selected to be suitable for the research. It was paid attention that the data collection tools used in the process focus on the research problem. It was thought that collecting data that was not related to the research would cause a waste of time and energy. For this reason, data were collected by paying attention to the problem situation during the research.

Content analysis and descriptive analysis were used in the analysis of the data collected in the study. Interview forms, observation forms, researcher diary and student diaries were analyzed through content analysis; In general, descriptive analysis was made in the worksheets applied to the students. 
McNiff \& Whitehead (2011) was based on the steps followed regarding ethical issues during the research.In addition, the research was carried out by the Governorship of Kayseri, Provincial Directorate of National Education, on 11.01.2018, by obtaining a permit numbered 94025929-609.02-E.852280.

\section{Results}

At the end of the research; The importance of eliminating the deficiencies in pre-listening acquisitions, detailed preparation for the text, and effective use of traditional and complementary assessment and evaluation practices have been recognized. In addition, according to the nature of the listening text, the number of listening, listening style and determining the way the listening text is presented; original listening text and subject; it has been revealed that the quality of listening texts, sound files and visual aided materials has an effect on the process.

\section{Discussion and conclusion}

At the end of the research; the importance of eliminating the deficiencies in the acquisitions before listening, making detailed text preparation practices, and effective use of traditional and complementary assessment and evaluation practices has been recognized. In addition, according to the nature of the listening text, the number of listening, listening style and determining the way the listening text is presented; original listening text and subject; It has been revealed that the quality of listening texts, audio files and visual aided materials has an effect on the process.

The research carried out; It is thought to have important results in terms of including practices for the development and development of listening skills, changing students' perceptions of listening texts, contributing to the development of students with practices aimed at determining the development of listening skills and development status, and shedding light on future research by recognizing the deficiencies and inaccuracies in the practices. The fact that the study was conducted with an action research design within the framework of qualitative research approach enabled the dynamic process of the course to be reflected from different angles.

Practices and researches in the field affect the development of listening skill. For this reason, it is thought that studies based on the development of listening skill and the practices carried out for the development state will contribute to the listening skill. 